\title{
Toronto's Little India: \\ A Brief Neighbourhood History
}

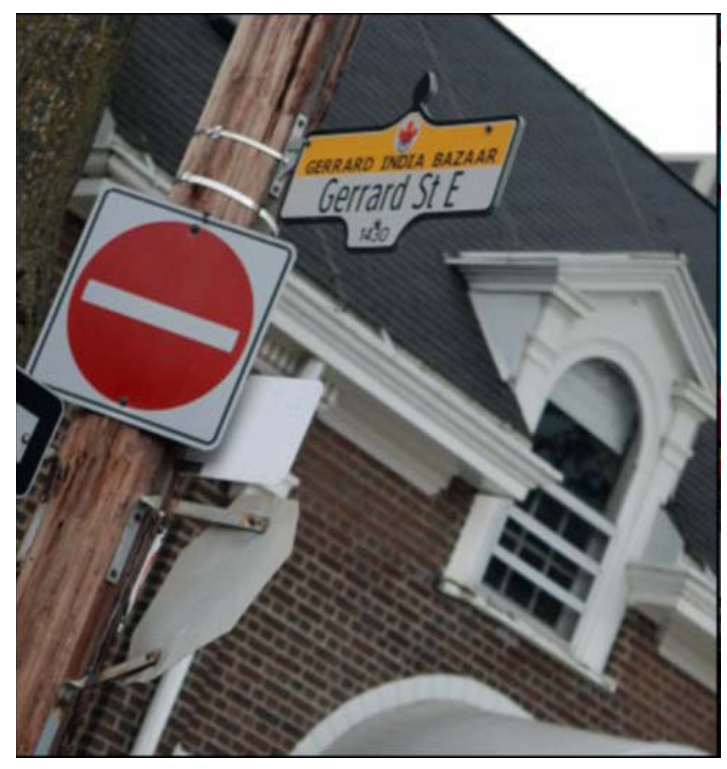

Harald Bauder \& Angelica Suorineni

RYERSONUNIVERSITY 


\title{
Toronto's Little India: \\ A Brief Neighbourhood History
}

\author{
Harald Bauder \& Angelica Suorineni \\ Ryerson University \\ Toronto, 2010
}

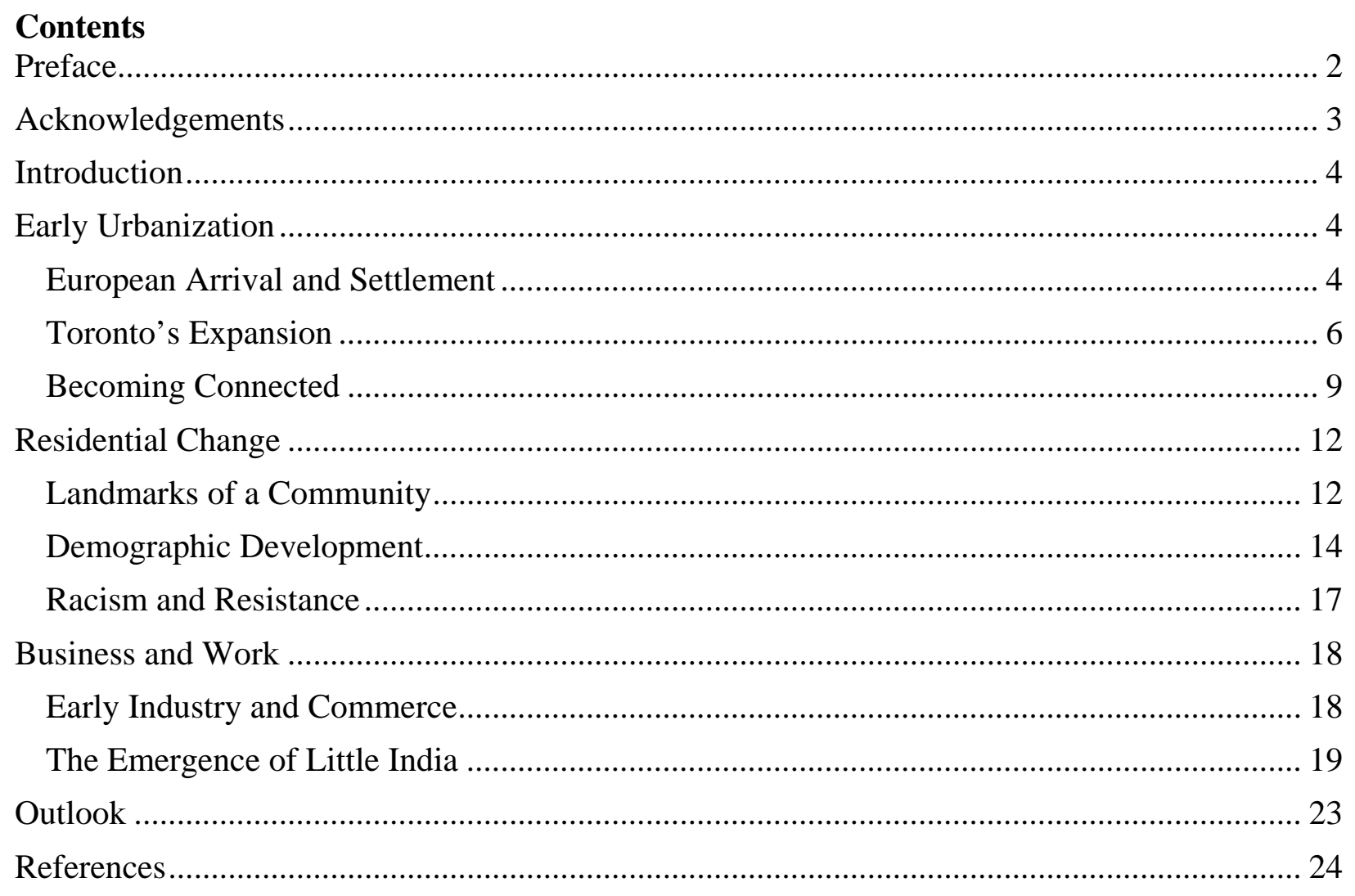

(c) $(1)(9)$

Creative Commons Attribution-Noncommercial-No Derivative Works 2.5 Canada License 


\section{Preface}

This historical survey of Toronto's Little India neighbourhood began in November 2009, with an email circulating among faculty members of Ryerson University with research interests in immigration and settlement. In this email, Laura Thomas of the Riverdale Immigrant Women's Centre (RIWC) requested assistance to conduct a neighbourhood survey of the Gerrard-Coxwell area: "We are located in such a diverse cultural and physical landscape, and are interested in understanding our history of immigrant settlement patterns". The ultimate aim would be to provide the community with historical, geographical, social and cultural information as a resource for local revitalization and economic development, community engagement and support of the arts and environmental groups.

In an initial meeting with Nuzhath Leedham, the executive director of RIWC, Harald Bauder learned about a "cultural mapping project" that was conducted earlier in the year in Chinatown, and which RIWC sought to replicate for the Gerrard-Coxwell area. After a closer look at this project, it became clear that replicating Chinatowns' "cultural mapping project" was not feasible, given the resources available and university-based constraints on research ethics. Instead, we decided to conduct a more "conservative” study of Little India's neighbourhood history. Although the term "mapping project" continued to circulate through the community to describe this survey, our project is more about compiling and summarizing a neighbourhood history.

As a resident of the Little India neighbourhood since November 2008, Harald Bauder's contribution to this report is inspired by William Bunge's (1971) book Fitzgerald, a groundbreaking work of humanist geography, presenting the history, development and contemporary challenges of a particular neighbourhood of Detroit. Angelica Suorineni spent countless hours in the library and archives as a graduate student researcher. Although it would be preposterous to claim that this brief report could be of similar sophistication, scope or impact as Fitzgerald, we hope, like Bunge, that it will serve the community.

Harald Bauder \& Angelica Suorineni Toronto, July 2010 


\section{Acknowledgements}

We thank the following persons, without whose knowledge, community dedication and personal initiative this report would have been impossible: Nuzhath Leedham, Executive Director of the Riverdale Women's Centre, Gail Ferguson and Severino Ziorli of the Gerrard/Ashdale Branch of the Toronto Public Library, as well as Doug Fyfe, a local historian, and local resident Diane Dyson.

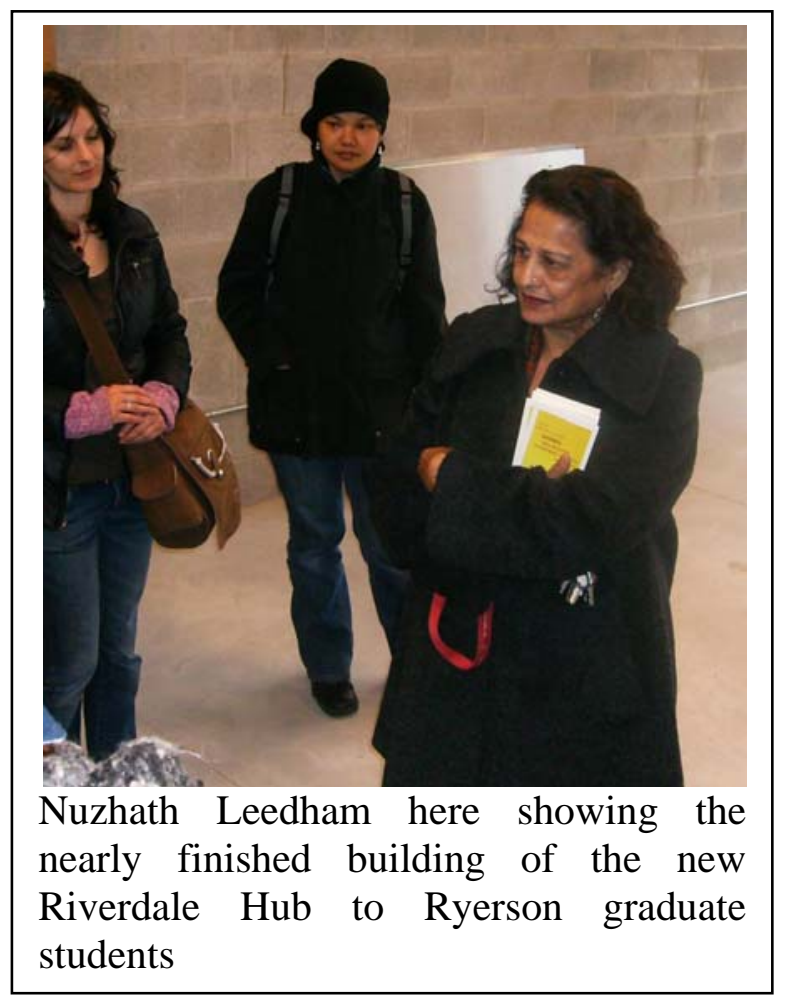

This report was made possible by a graduate student research assistantship funded by the Graduate Program in Immigration and Settlement Studies (MA) in the Faculty of Arts at Ryerson University.

All errors that remain in this report are ours.

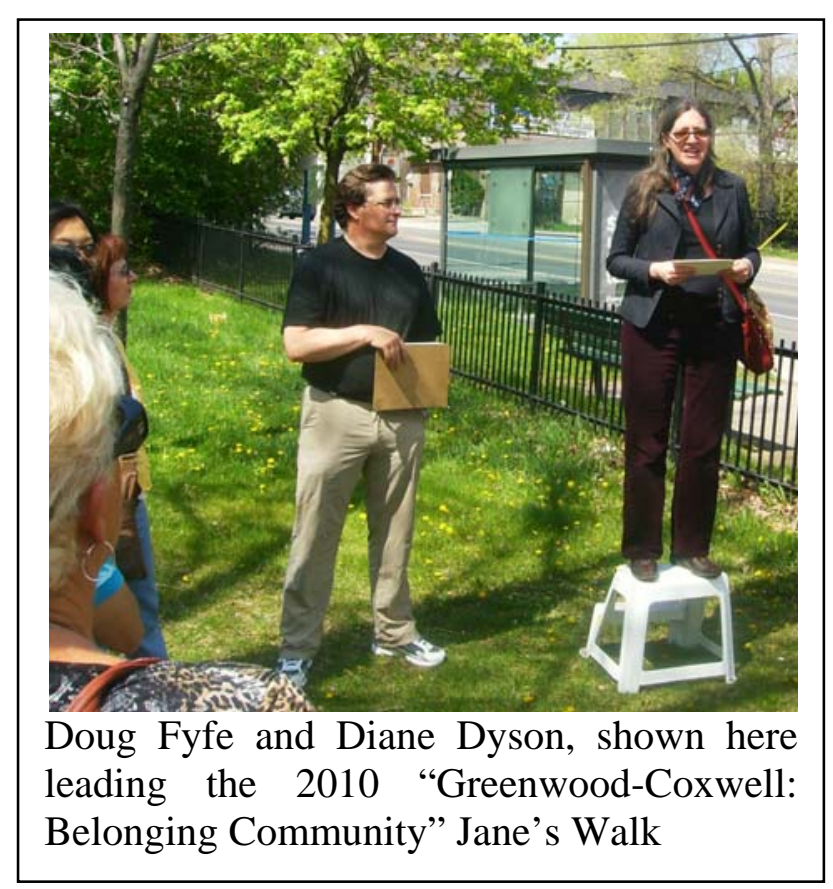

We also thank Will Poppe, Ph.D. candidate at S.U.N.Y. and member of the Riverdale Immigrant Women's Enterprise Revitalization Committee, Subbu Chintaluri of the Gerrard India Bazaar Business Improvement Area, Pad Dudman, a life-long resident of the area, Yishin Khoo, Project Coordinator of the Chinese Canadian National Council (Toronto Chapter), Lisa Oliveira, Janet Malowany, Toronto City Councillor, Paula Fletcher, and Karen Uchic.

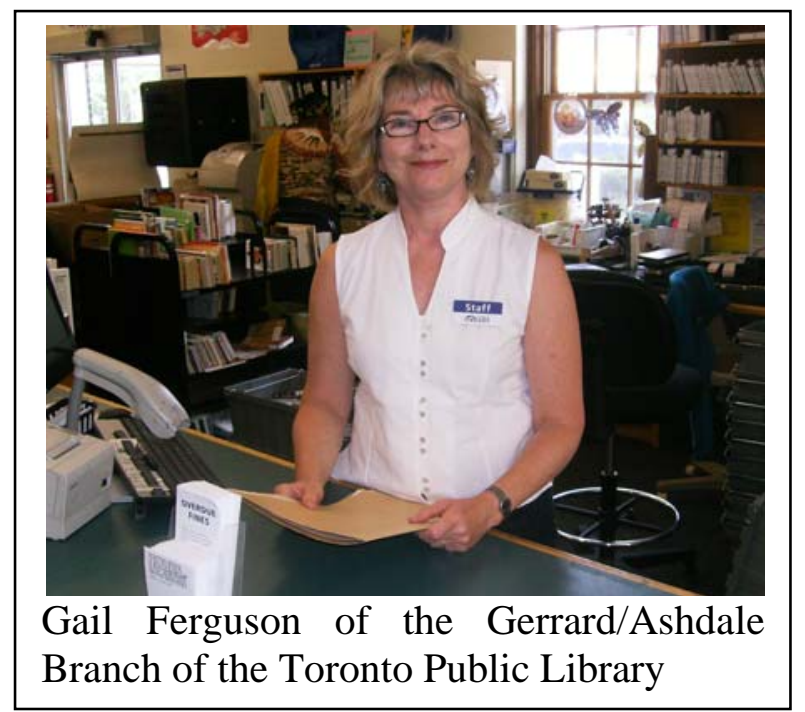




\section{Introduction}

Little India appears to be a split community. In a Toronto Life article, Cynthia Brouse (2005: 29) described this split in this way:

I used to tell people I lived in little India, but I learned that was a misnomer, implying the existence, either today or in the past, of a large number of east Indian residents. In fact, only a handful had ever lived there. The moniker applied by the local merchants, "Gerrard India Bazaar" does a better job of describing what is really a business district that serves a distant clientele.

Similarly, the Toronto Star's 2009 “neighbourhood map” did not assign any distinct identity to the neighbourhood and allocated the area south of Gerrard St. to Leslieville. Recently, residents of part of the area north of Gerrard St. have formed a residents association assigning the area the label "Ashdale Village”.

In an effort to understand the current "dissonance between commercial and residential identity" (Hackworth and Rekers, 2005: 229), we explore in this report the history of the area we continue to describe as Little India. We believe that to understand (and perhaps help to construct) an inclusive identity of a place, it is important to not only to consider the residents and businesses of today but also know about the local people, events and circumstances of the past.

In this report, we investigate the contexts of urbanization, residential change, and business and work related to Little India from early settlement to the contemporary period. Although this historical overview is brief and incomplete, we hope that it will trigger the reader's interest in further exploring this neighbourhood's identity.

\section{Early Urbanization}

\section{European Arrival and Settlement}

The settlement of the area by First Nations in not well documented. Early records of the area date back to John Graves Simcoe, who was appointed Lt. Governor of Upper Canada in 1791. Simcoe initiated surveys of the new town site of York, where he decided to reside and proposed to situate the provincial government. Barracks, public buildings and roads were built on this land soon thereafter. In 1796, a plan of the Township of Dublin, later York, divided the waterfront of Lake Ontario into 35 township lots, ranging from Balmy Beach in the east to a point south of today's High Park in the west. Dividing lines ran south from Queen St. to the shoreline. In 1792, Simcoe issued a proclamation with the intention of settling the land. The offer included free land to anyone who had "good character" (defined by being a church member and not having a reputation for rowdiness or illegal activities) and was willing to swear allegiance to the British government (Beverly, no year).

The Ashbridges, a farming family from Pennsylvania, were attracted by this offer. Sarah Ashbridge, who was widowed, arrived in 1793 with five of her children, including two of her daughters with their husbands and children. The family arrived on a small boat, which they took across Lake Ontario, and landed on a sandbar enclosing a bay east of Don River later given the name Ashbridge’s Bay. Sarah and her two sons were granted 200 acres of land, which together 
formed a block of 600 acres, approximately $1 \frac{1}{2} 2$ miles east of the Don River. Other land owners included Parker Mills and Paul Wilcott. Wilcott was married to one of the Ashbridge's daughters (ibid).

The Ashbridge’s Family Home, located at 1999 Queen St. E., 1981

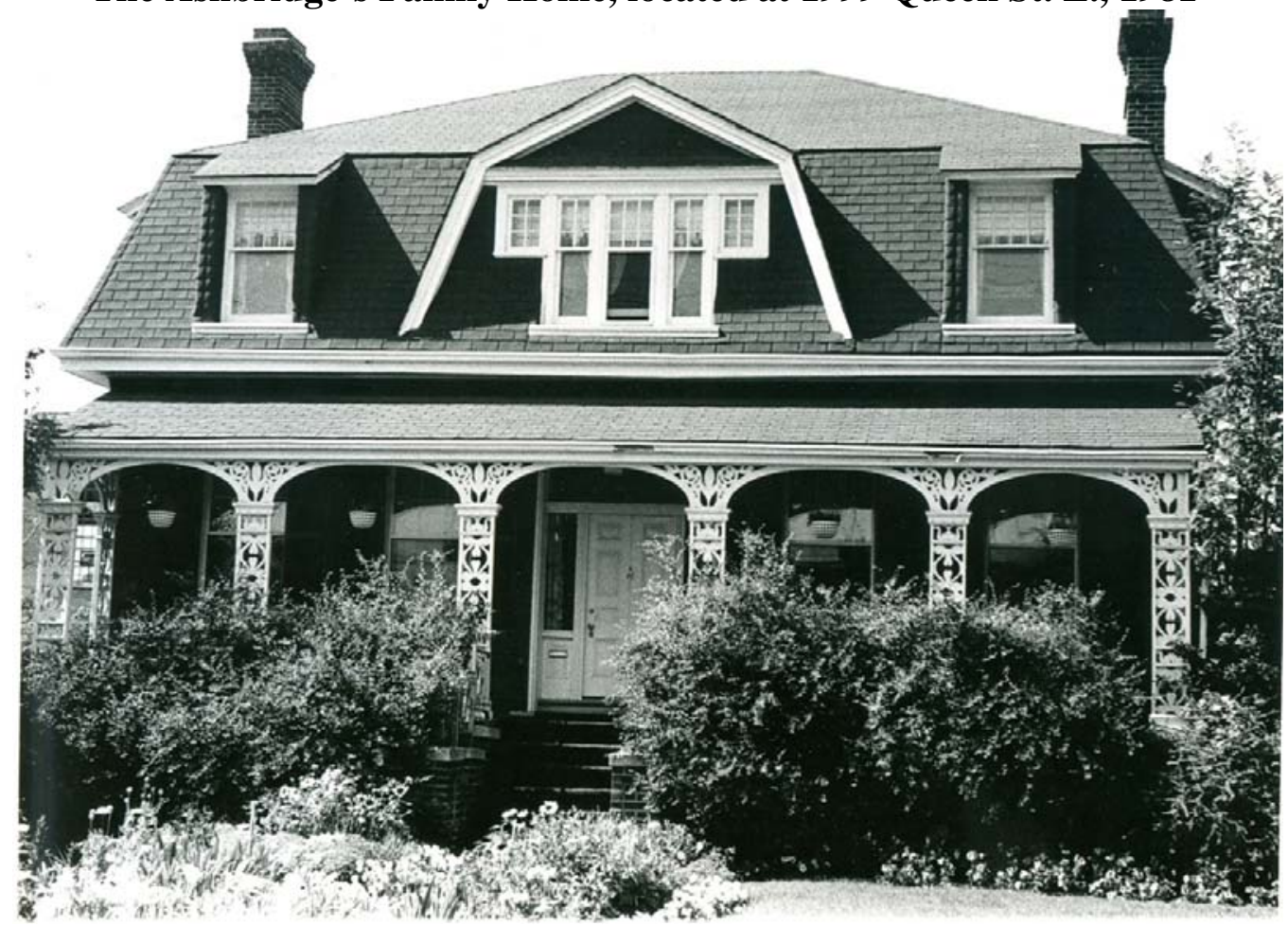

Source: Toronto Public Library Archives

The Small family played a prominent role in the area's history. Their property included 500 acres of lots 6, 7, 8 of York Township, extending from the shore of Lake Ontario to Danforth Ave. Peter Small built Coxwell Ave., named after his son Charles Coxwell Small. According to George Dodd (1964: 52-53), "Small put a reserve along the east side of the street and found himself in a legal tangle with the son of the City Assessor, a Mr. Ormrod, who, as a beneficiary under a will, held title to certain lands thereabouts." Charles Coxwell Small gave three acres of his land to St. John's Church, located near the village of Norway, at the junction of Kingston and Woodbine (Beverly, no year) ${ }^{1}$.

Hugh Cochran reportedly was one of the first European settlers west of Coxwell and built a house on the corner of what today is Walpole Avenue and Woodfield Road - the old fame lane from the estate. Cochran and his family also constructed several houses in the area. Local stories exist of a native tent settlement north of Gerrard St. near Greenwood Ave.

\footnotetext{
${ }^{1}$ Reportedly, the church building was originally a schoolhouse that the Ashbridge brothers hauled by oxen to the new site. A new church built in 1893, designated a historic site in 1977.
} 


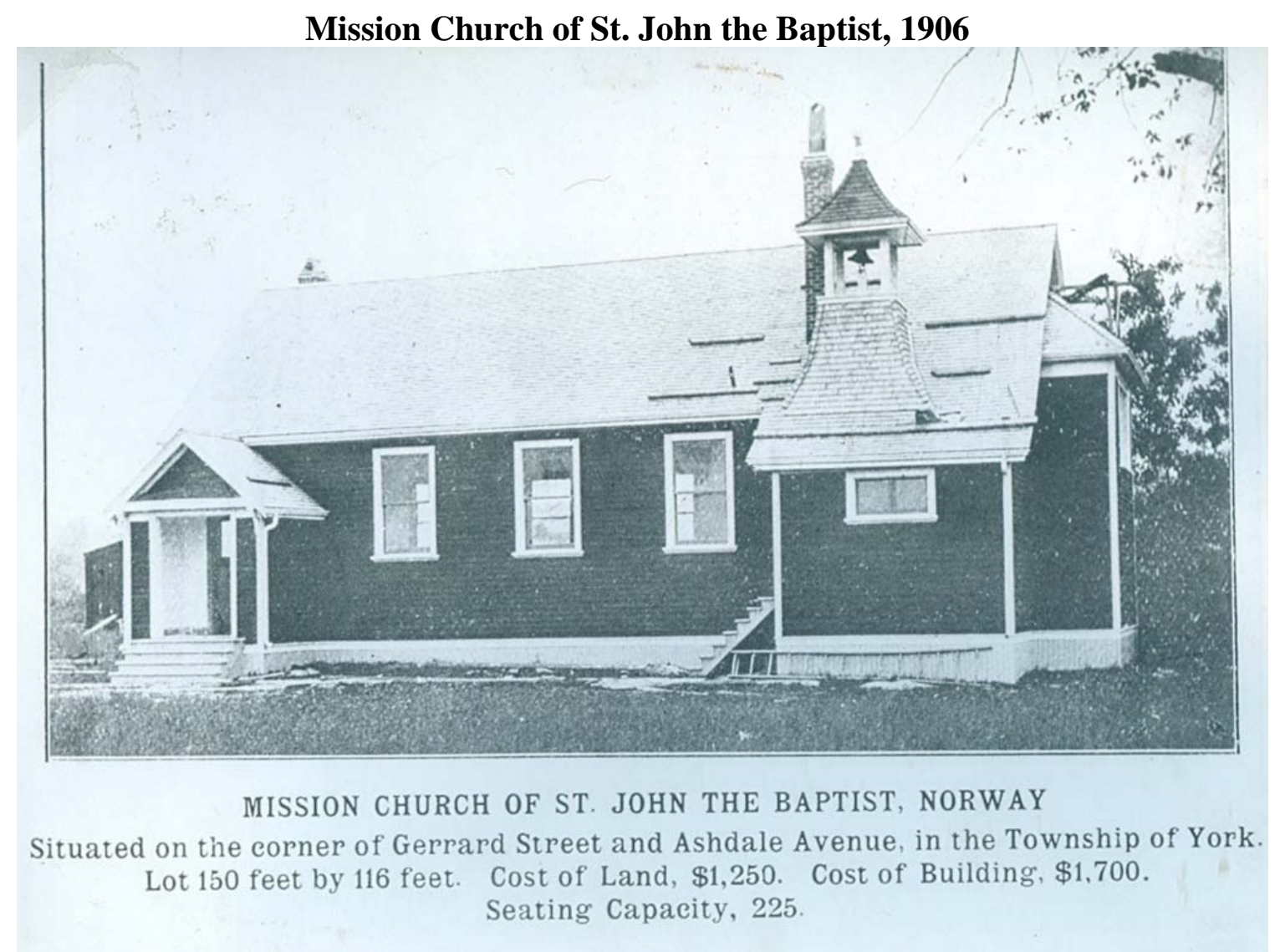

Source: Toronto Public Library Archives

\section{Toronto's Expansion}

In the late $19^{\text {th }}$ and early $20^{\text {th }}$ Centuries, the area bordered by the Danforth to the north, the Woodbine race course to the south, Greenwood Ave. to west and Waverly Rd. (east of Woodbine) to the east was known as Midway (see map below). The first race on the Woodbine Race Course took place in fall of 1875, organized by the Toronto Jockey Club. Compared to its surrounding areas, Midway was sparsely populated, with the Village of Norway being the main population cluster (Beverly, no date; Guillet, 1946).

Due to its location, low population density and associated difficulties to deliver services, Midway was a candidate for annexation. Local wells were beginning to dry up, leading to health and fire hazard concerns, sewers were unavailable, mail needed to be picked up in the city, streetcars only went to the edge of Midway, and two schools on Ashdale Ave. and Norway were filled to capacity. Furthermore, land speculators hoped that annexation and the associated availability of city services would increase property values. Midway was annexed by Toronto on December 15, 1909 (ibid).

The history of the area was shaped by developments on Ashbridge's Bay. The bay was formed by a sandbar extending from the western town line of Scarborough at an angle into the lake, and curved back to the land without quite touching the boundary of the Town of York. The sand spit was split into eastern (Ashbridge’s Bay) and western (York Harbour) parts. Ashbridge's Bay was too swampy and marshy to be used as a harbour, and its stagnant waters caused health concerns. 
The dredging of the deeper parts of Ashbridge's Bay and the filling of the marshy and shallow parts was finally completed in 1895. The land created by in-fill was intended for recreational purposes, such as Cherry Beach, and industrial uses, including bulk industries that required large amounts of storage space. ${ }^{2}$

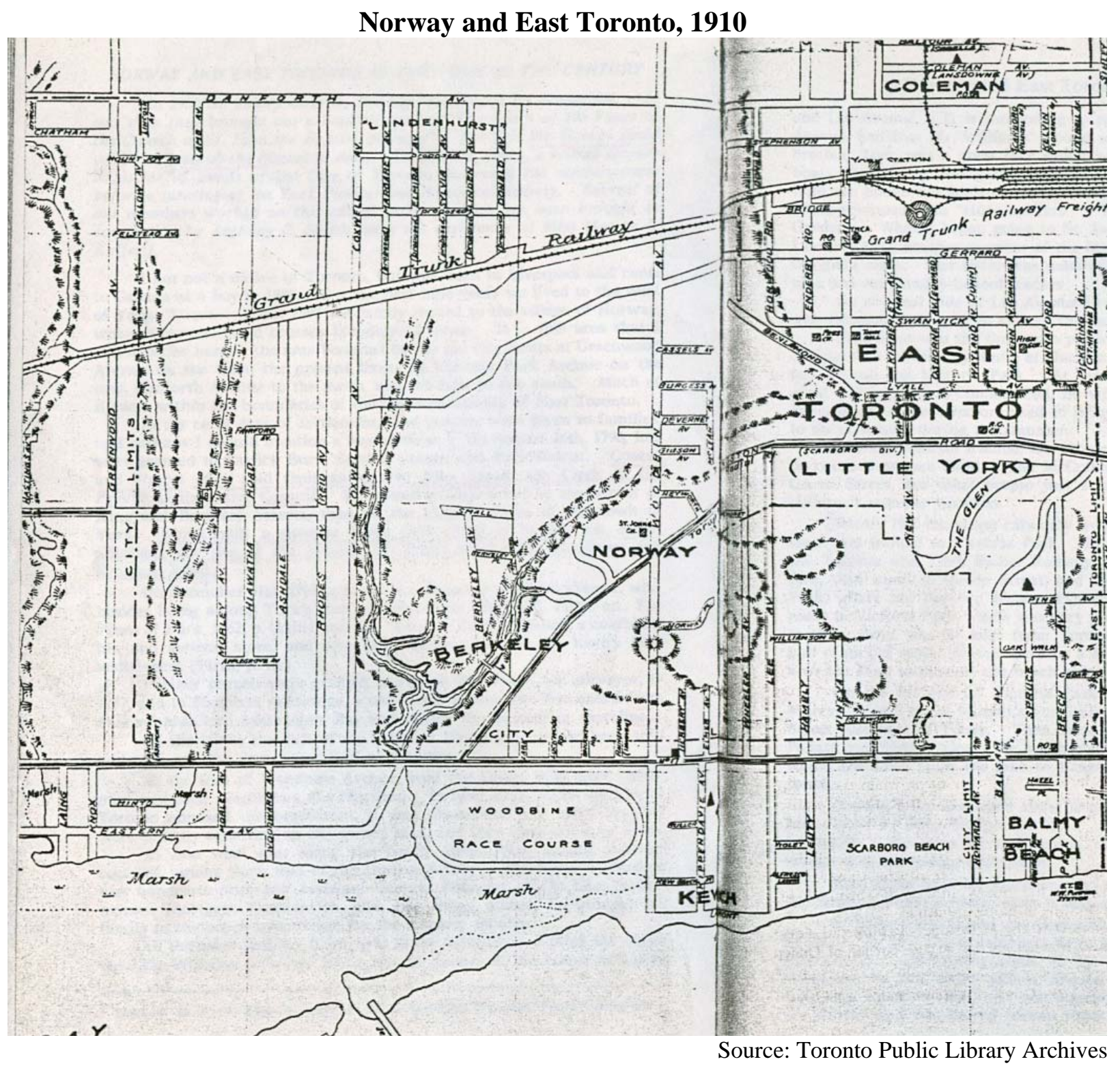

${ }^{2}$ Today, Ashbridge's Bay is the small bay at the end of Coatsworth's Cut and at the foot of Coxwell Ave. 
Two Views of Ashbridge’s Bay, 1910
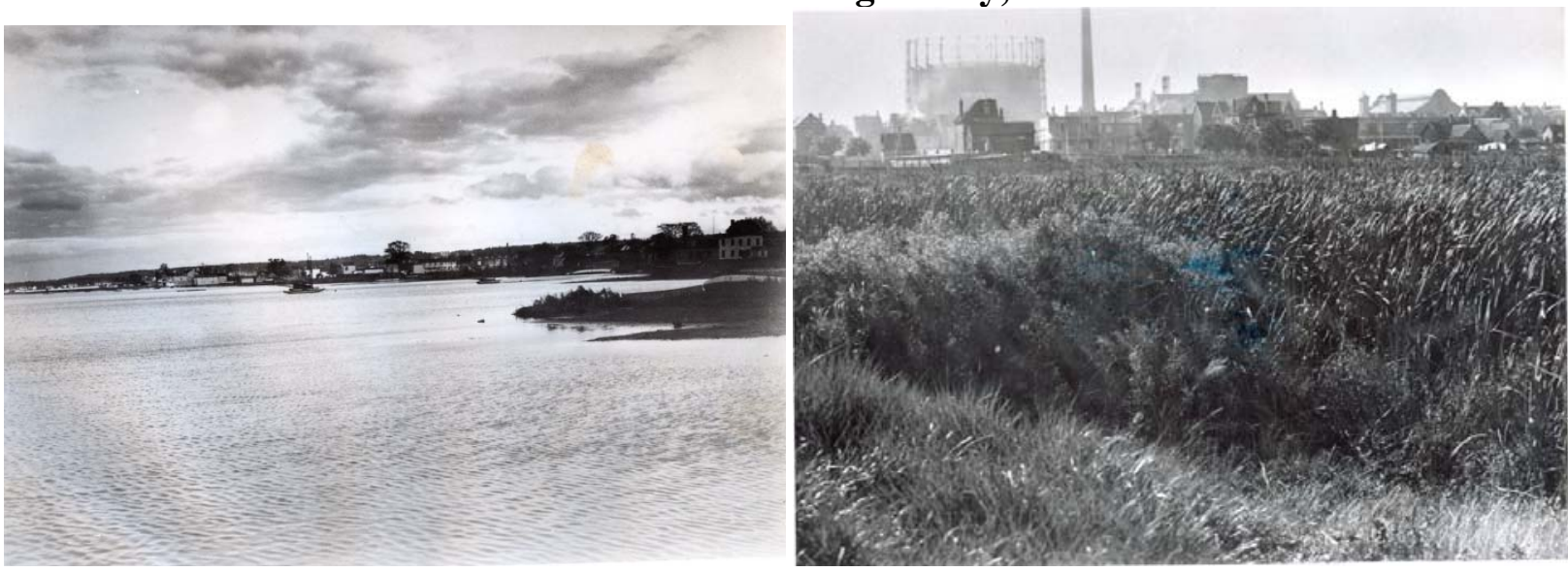

Recreational Activities at Ashbridge's Bay, 1910

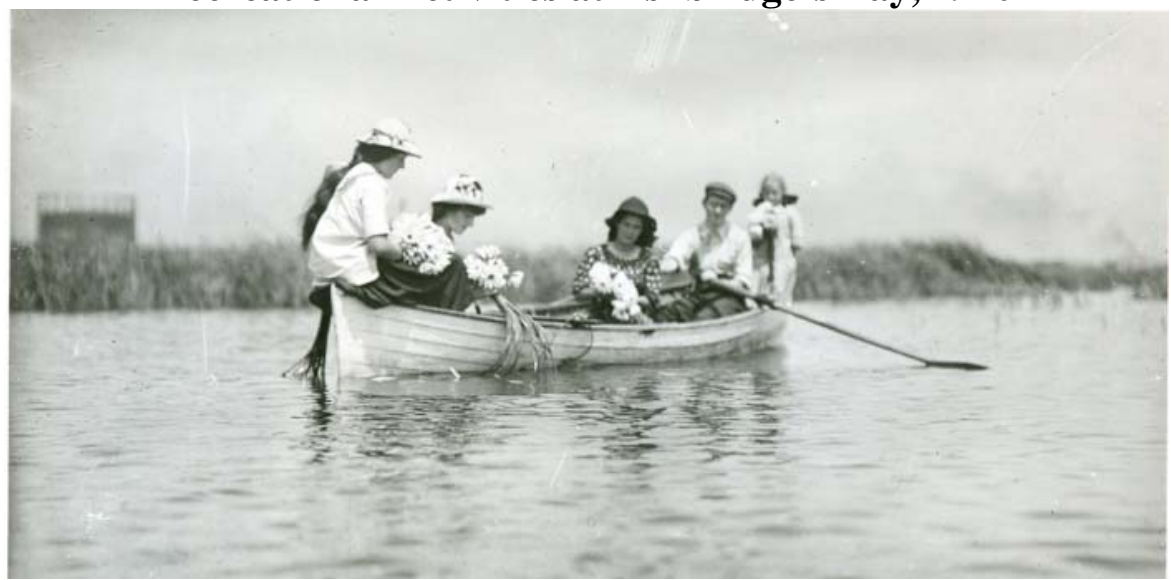

Industrial Uses in Ashbridge’s Bay, 1912 and 1915
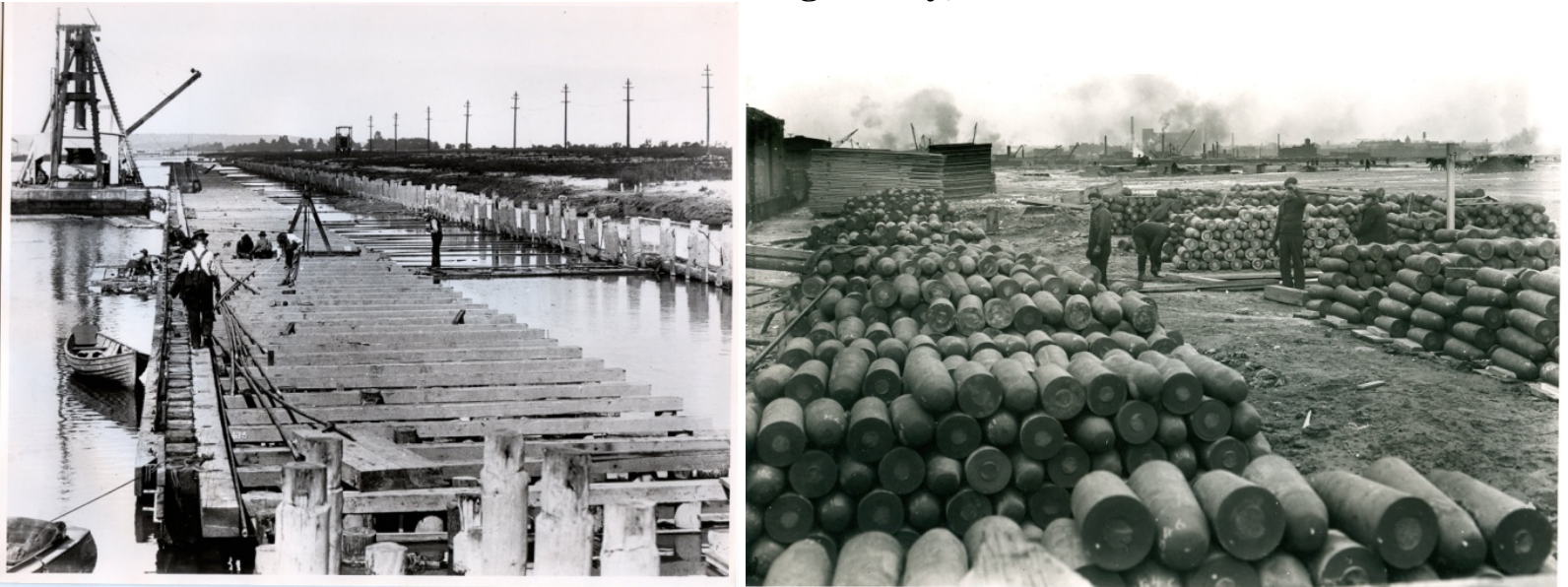

Source: Toronto Public Library Archives 


\section{Becoming Connected}

Transportation played a defining role in the development of the area. In the early $20^{\text {th }}$ Century, local infrastructure improved dramatically, streets were electrified and paved, as the sequence of photographs below illustrate.

\section{Woodbridge Road, Jesse Ashdbridge Farm, 1906 (left) and Ashdale Ave., 1908 (right)}
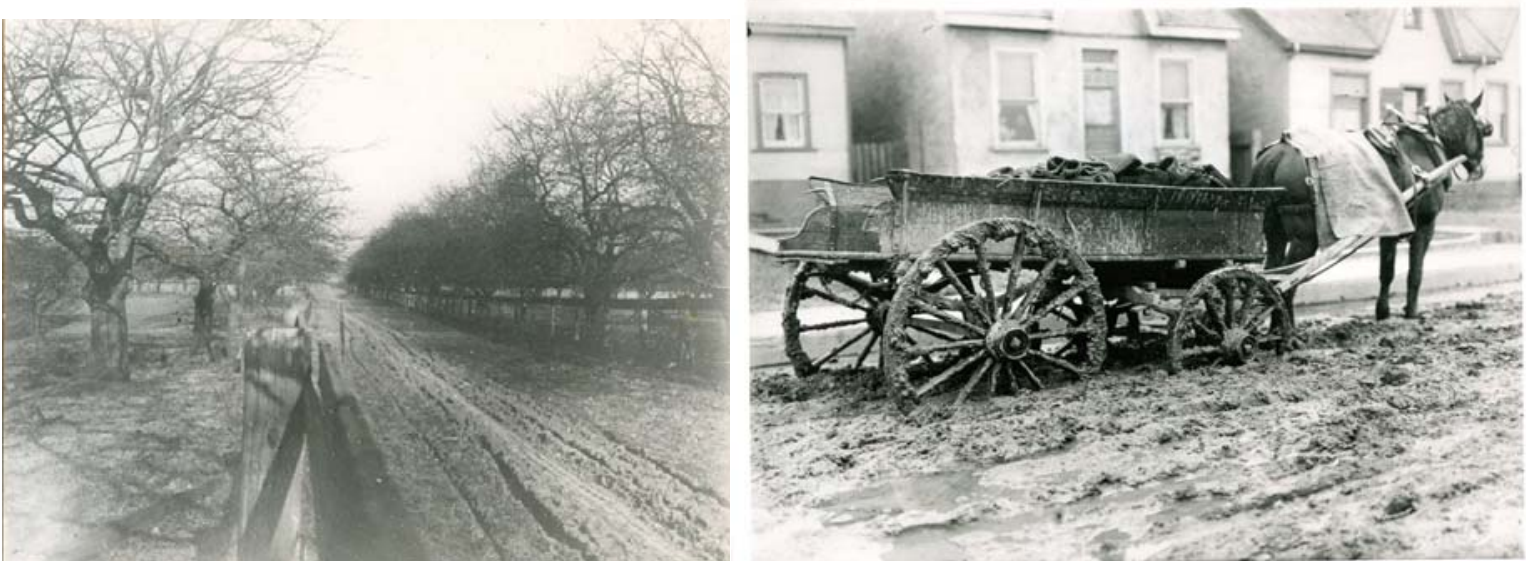

Gerrard St. E., 1911 (left) and Rhodes Ave., North of GTR, 1913 (right)
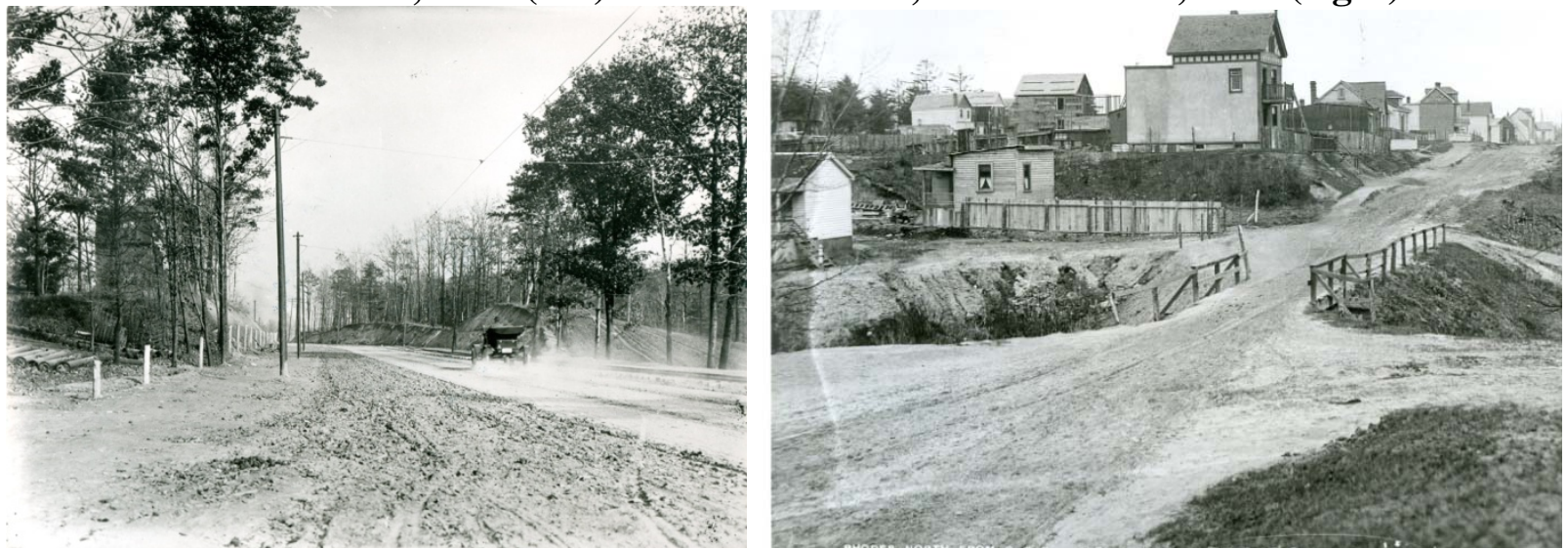

Gerrard St. E. at Greenwood, 1914 (left), Woodfield Ave., 1929 (right)
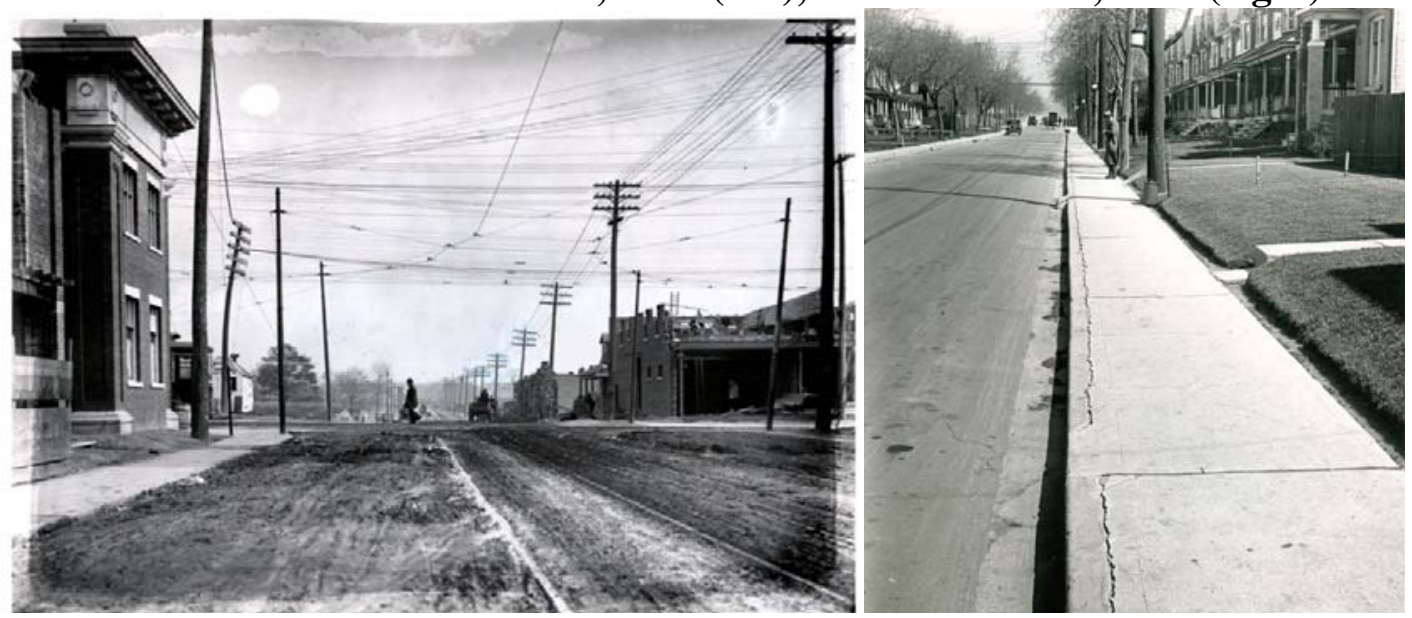

Source: Toronto Public Library Archives 
Prior to the inception of the T.C.R (Toronto Civic Railways) ${ }^{3}$, in 1911, Danforth Ave. and Gerrard St. (east from Greenwood Ave.) lacked connections to public transportation routes. The Gerrard "civic car” route was established in 1912 and was the first local streetcar line. It started at the terminal of the Toronto Railway's Parliament line at Gerrard and Greenwood, went eastward to Gerrard and Main St. and then entered east Toronto. The route was double tracked and powered by the East Toronto pumping station, located at the east end of the terminal at Gerrard and Wayland Ave. The Danforth civic route followed in 1913. These connections provided more convenient access to the east Toronto area and triggered rapid development of the area (TTC, 1953).

Toronto Civic Railways, 1921

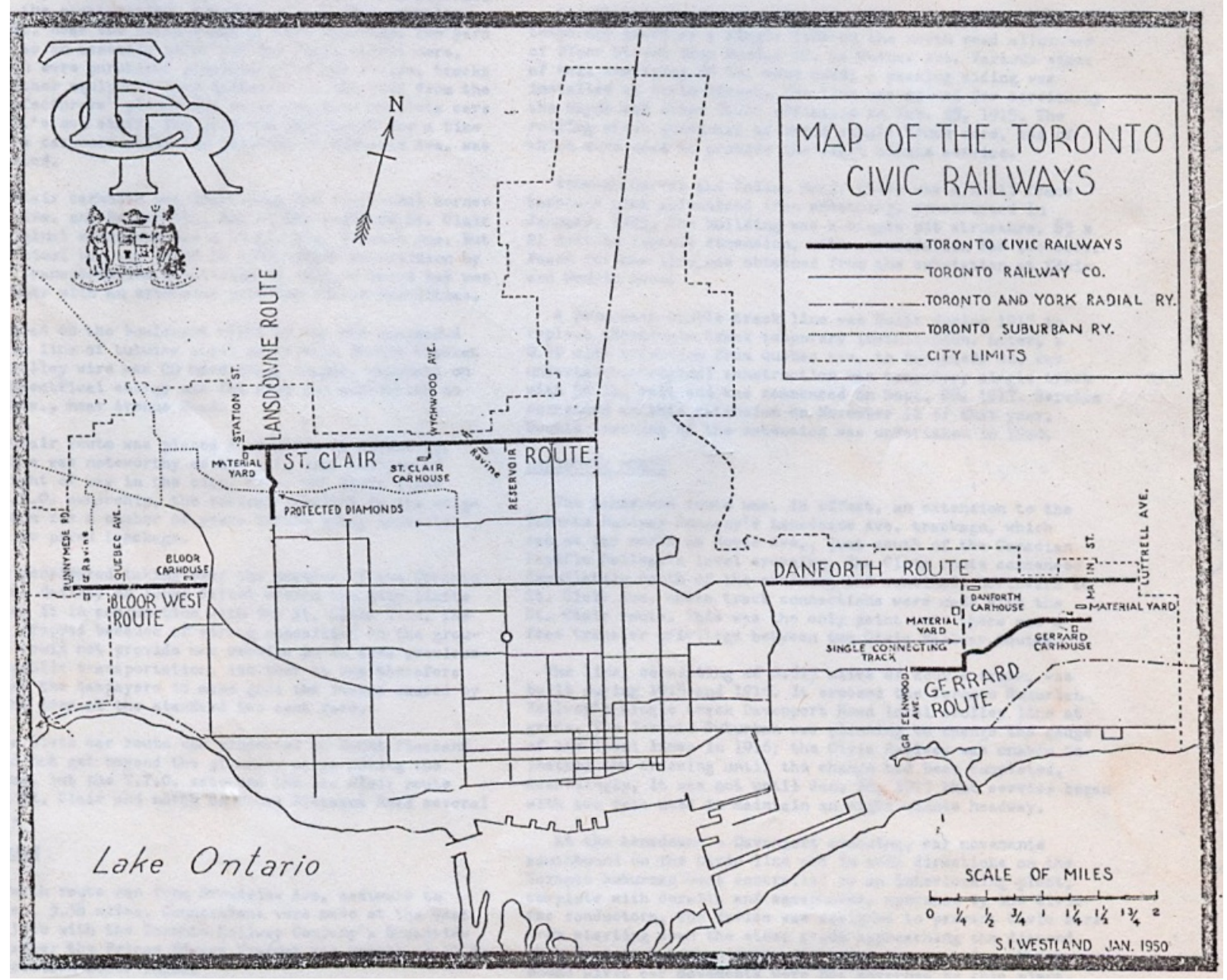

Source: Toronto Public Library Archives

${ }^{3}$ The Toronto Transit Commission (TTC) succeeded the nine separate and privately owned T.C.R. routes. 
Digging at Gerrard St. East, 1911

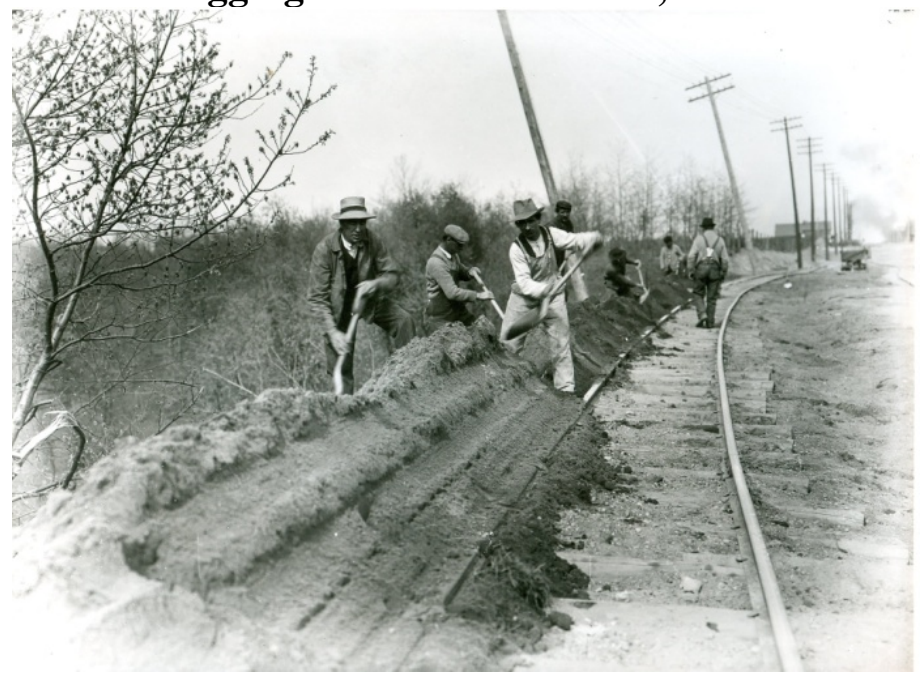

Track work at Coxwell Avenue and Upper Gerrard, August 23, 1921

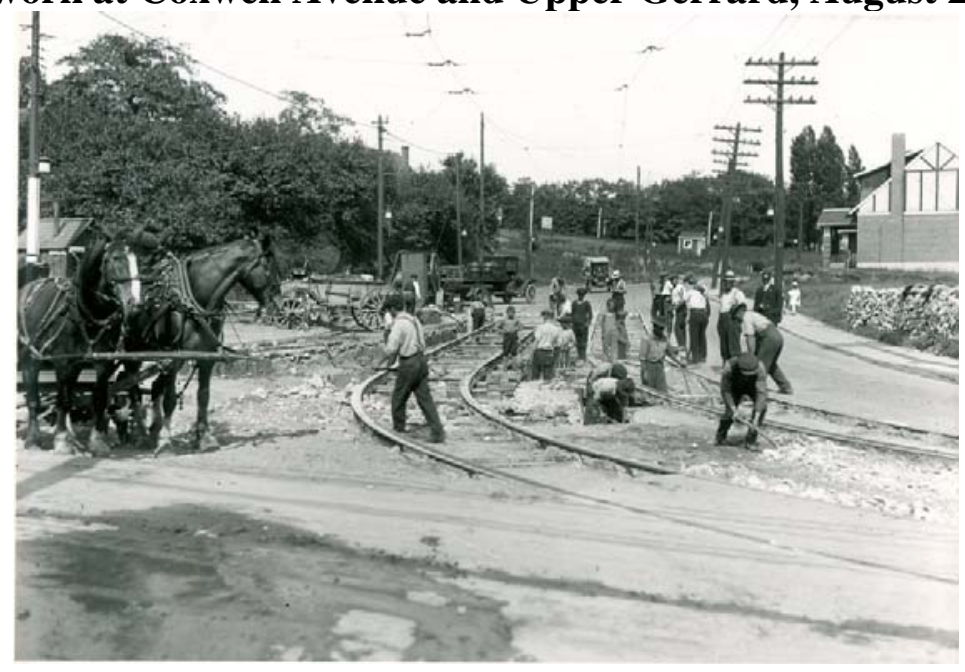

4385 Gerrard Street East and Coxwell Avenue, June 17, 1926

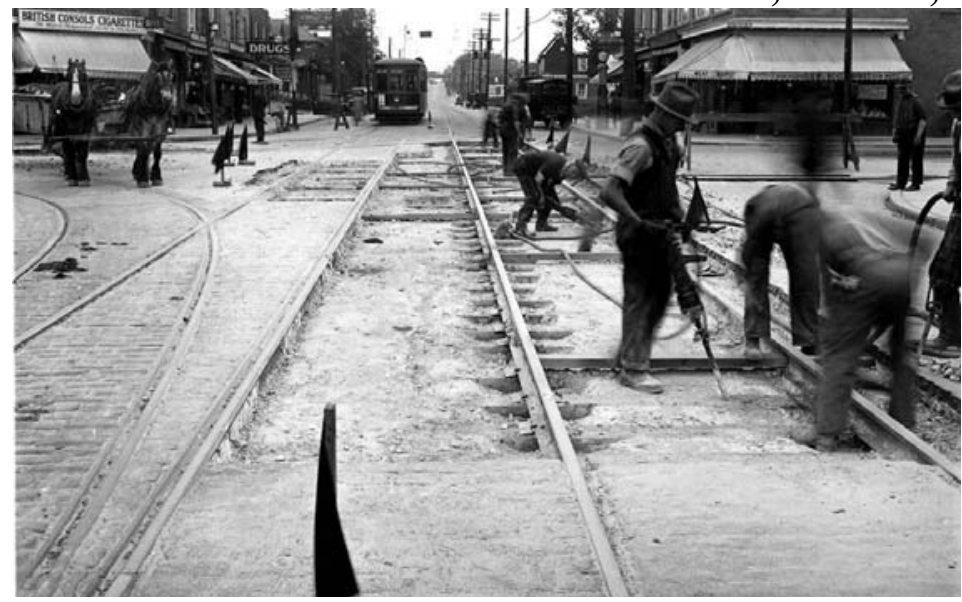

Source: Toronto Public Library Archives 


\section{Residential Change}

\section{Landmarks of a Community}

The area north of the Greenwood Racetrack (formerly Woodbine Race Course) has been considered part of the Riverdale community. The development and change of the residential area north and south of Gerrard St. can be illustrated by the history of several local landmarks. In 1906, a small brick building was erected at the northwest corner of Reid Ave. (renamed Rhodes Ave. in 1909) and Gerrard St. to house a mission sponsored by Bloor St. Presbyterian Church. After the union of the Presbyterian and Methodist Churches in 1924, a new church building was constructed in 1926, which today is a major landmark on Gerrard St. (Glen Rhodes United Church, 2010).

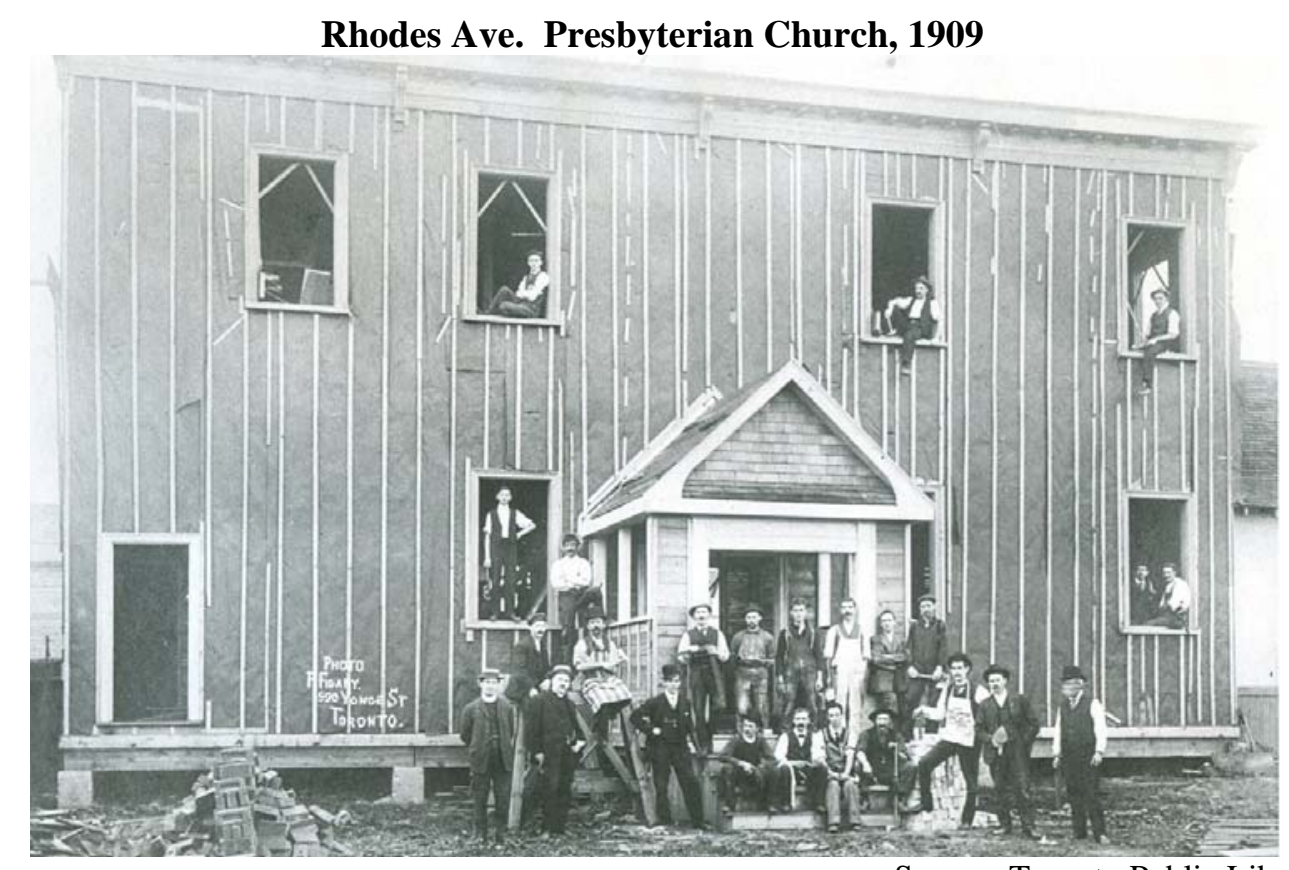

Source: Toronto Public Library Archives

The Orange Order had a local presence with the Orange Hall on Rhodes Ave. between Gerrard St. and Dundas St. In 1917, the Gospel Group the Christians began renting the hall (also known as Dian Hall) for \$10.00 a month. Later, it was the home of the Glasgow Rangers Supporters Club, a local soccer team support group. After initiating a search for a new property in 1969, the Islamic Foundation of Toronto purchased the building but later moved to a larger facility in Scarborough (Nazir, 2009; Broadview Gospel Hall, 2001).

The area had other prominent public and recreational facilities. The Coxwell Stables (on Cowell Ave. just south of the train tracks) were built in 1919 to accommodate the horses that pulled Toronto's Public Works Department vehicles. After the horse-drawn vehicles were replaced with automobiles, trucks and other machines, the stables were used mainly as a storage facility. In 1981, the Toronto Historical Board designated the building a historical site and CityHome, the City of Toronto's non-profit housing company, subsequently bought and renovated the site to offer affordable rental housing (Canada Mortgage and Housing Corporation, 2010; Toronto Community Housing, 2010). 
Coxwell Stables, 1925

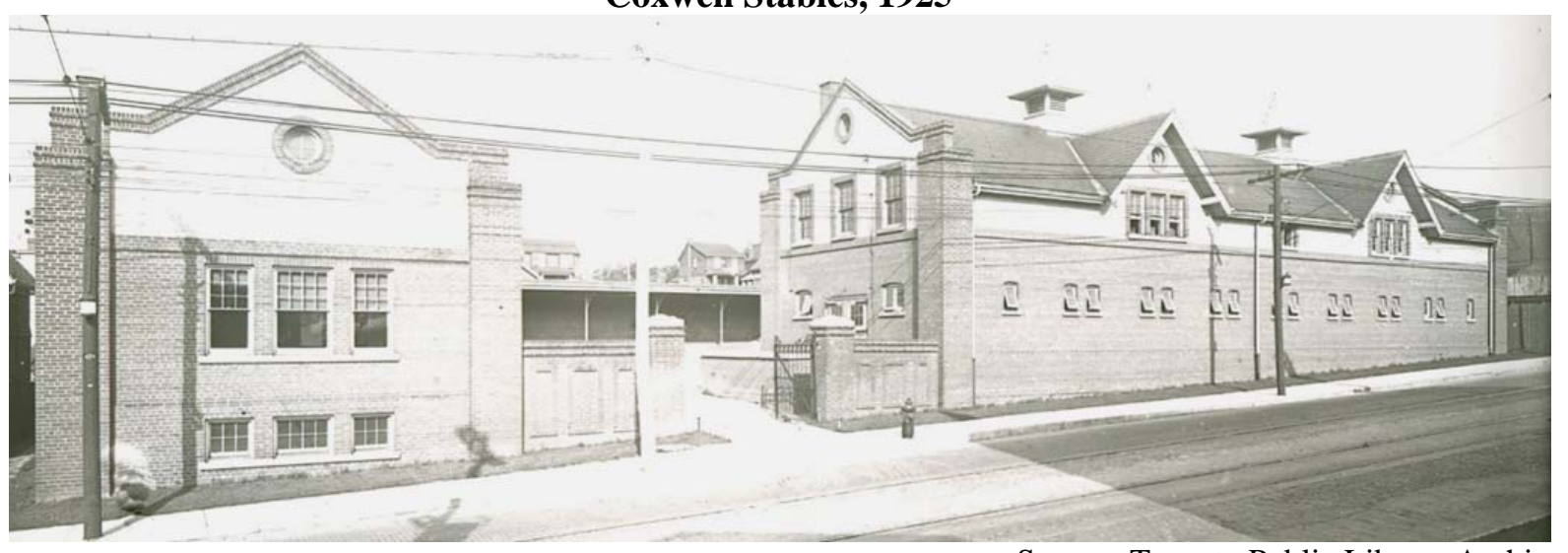

Source: Toronto Public Library Archives

Ulster Stadium was reportedly located south of Gerrard St., between Woodfield and Greenwood. In 1930 the first football game in Eastern Canada under floodlights was played between Oshawa and Toronto Balmy Beach at Ulster Stadium (CFL, 2010). Today, the Ulster Arms Tavern, located on the south-side of Gerrard St. between Greenwood Ave. and Highfield Rd. and Athletic Ave., is among the few reminders of this part of the neighbourhood's history.

With the residential development of the area came the establishment of other recreational public facilities. Greenwood Park, for example, was established at the site of a former clay mine, which supplied the local brick industry. The Gerrard/Ashdale library was established in 1924 and became a centre of community life. An addition was added to the library in 1977 (Beverly, no date).

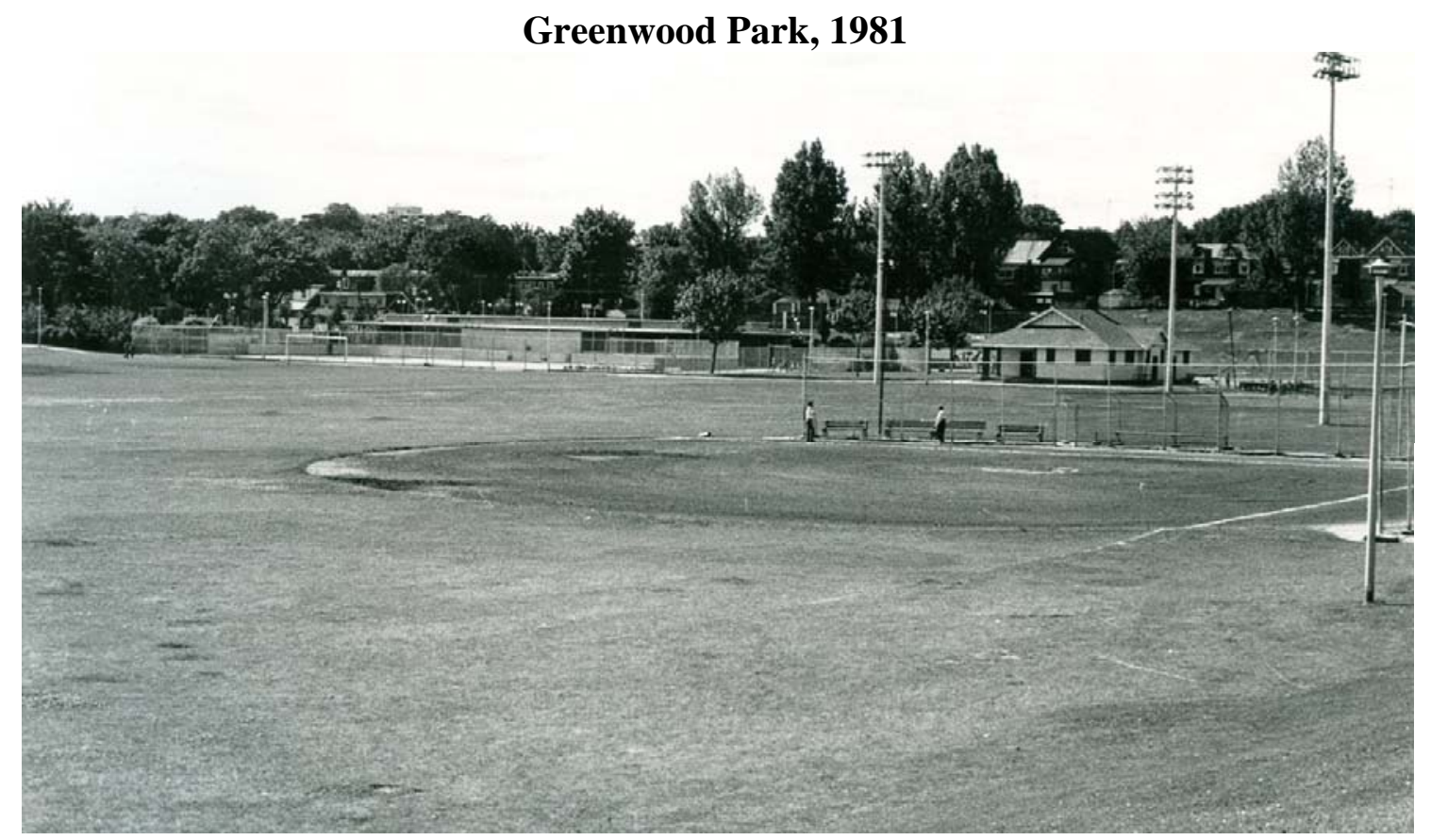

Source: Toronto Public Library Archives 


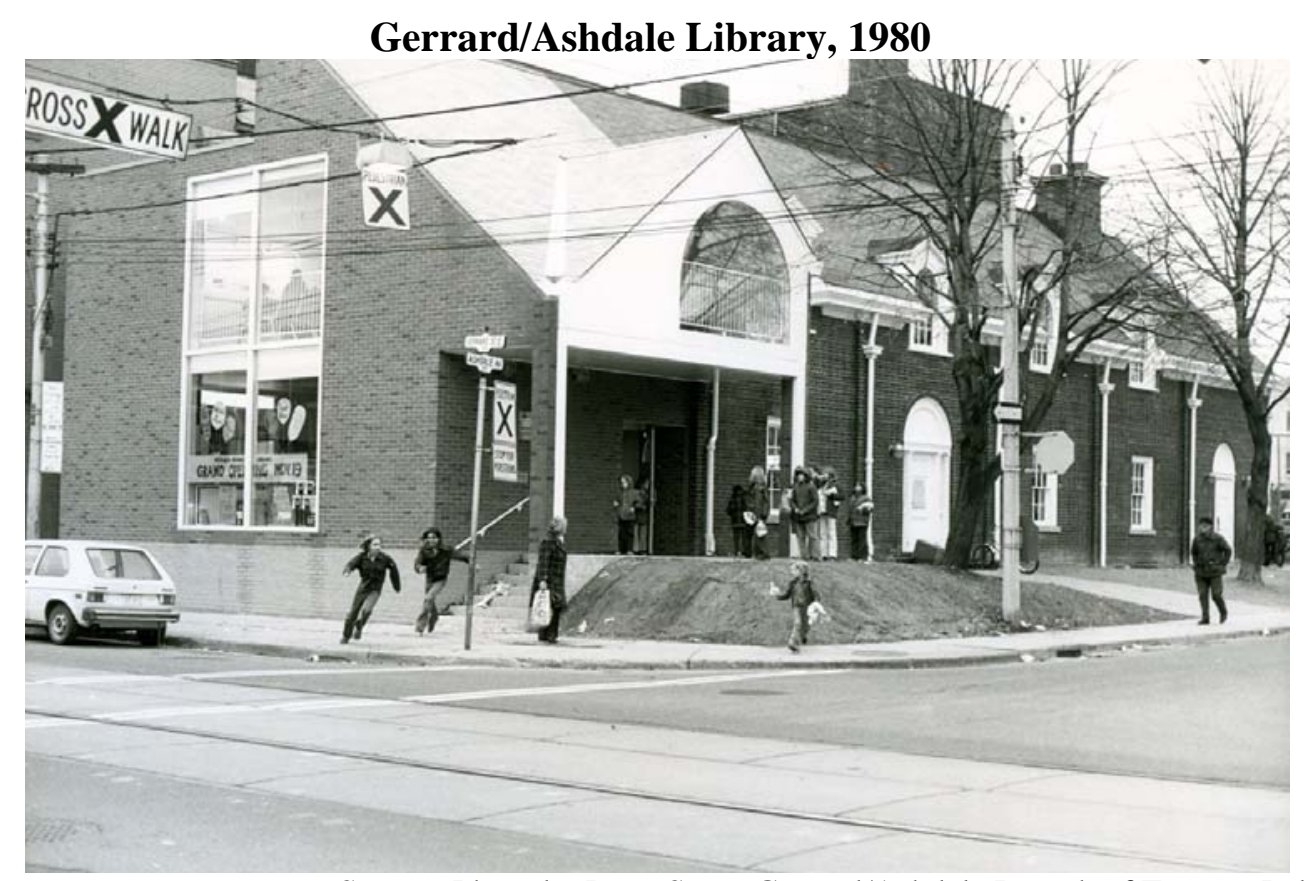

Source: Photo by Peter Scott, Gerrard/Ashdale Branch of Toronto Public Library

\section{Demographic Development}

In terms of local ethnic identity, the area was initially settled by working-class English, Irish and Scottish families. Until World War II, the area had an image of an Anglo, working-class neighborhood of TTC workers, police officers, Eaton's clerks and railway workers. In the second half of the $20^{\text {th }}$ Century, Italian and Greek immigrants were reported to settle in the area. Some of these families moved on to suburbs, such as East York and Scarborough, where larger homes were available. At the same time, Chinese and South Asians were attracted to the relatively inexpensive housing stock (Acarya, 1997; Brouse, 2005; Stein, 1984).

Gerrard St. represents a dividing line between separate administrative units. Since the redrawing of Toronto's riding boundaries in 2000 the area north of Gerrard belongs to City Council Ward 30 (which meanders west to the Don River and also includes Toronto's harbour); the area south is part of Ward 32, which extends into The Beaches. Similarly, the areas north and south of Gerrard are allocated to different census tracts: Census Tract 26 is bordered by Greenwood Ave. and Coxwell Ave. and from Gerrard extends south beyond Queen St.; Census Tract 74 is bordered by Greenwood Ave. in the west, Gerrard in the south, Coxwell in the east and the railway tracks in the north.

The most recent Canadian Census (Statistics Canada, 2006) provides a basic contemporary profile of the two census tracts north (74) and south (26) of Gerrard St. Between 2001 and 2006, both tracts experienced considerable population loss, compared to Toronto census metropolitan area (CMA), which gained population. 
Population Characteristics, 2006

\begin{tabular}{|l|r|r|r|}
\hline & $\begin{array}{l}\text { Census } \\
\text { Tract 26 }\end{array}$ & $\begin{array}{l}\text { Census } \\
\text { Tract 74 }\end{array}$ & $\begin{array}{l}\text { Toronto } \\
\text { (CMA) }\end{array}$ \\
\hline Population & & & \\
\hline Population in 2006 & 6,505 & 4,023 & $5,113,149$ \\
\hline Population in 2001 & 6,986 & 4,504 & $4,682,897$ \\
\hline 2001-2006 population change (\%) & -6.9 & -10.7 & 9.2 \\
\cline { 3 - 4 } & \multicolumn{3}{|c|}{ Source: Statistics Canada, Census, 2006}
\end{tabular}

The decline in population is likely related to the area's housing characteristics. Local housing stock is relatively old; the vast majority of it was constructed prior to 1986. Dwellings are relatively small, averaging only between 5 and $51 / 2$ rooms, compared to the Toronto CMA average of more than 6 rooms per dwelling. As the space-demands among average Canadian families have increased over time, local families tend to be smaller and more households are occupied by singles and couples without children. Thus, fewer individuals now live in the area than in the past. Accordingly, the size of the average household was below the Toronto CMA average. Only 2.4 and 2.5 persons lived in a local household in 2006, compared to 3.1 persons in 1976. Although real-estate values have been increasing, rents were (still) lower on average than in the Toronto CMA in 2006.

Housing Characteristics (Occupied Private Dwellings), 2006

\begin{tabular}{|l|r|r|r|}
\hline & $\begin{array}{l}\text { Census } \\
\text { Tract 26 }\end{array}$ & $\begin{array}{l}\text { Census } \\
\text { Tract 74 }\end{array}$ & $\begin{array}{l}\text { Toronto } \\
(\text { CMA) }\end{array}$ \\
\hline Single-detached houses (\%) & 18.5 & 17.6 & 41.7 \\
\hline Semi-detached houses (\%) & 23.5 & 16.3 & 7.7 \\
\hline Row houses (\%) & 8.5 & 2.5 & 8.3 \\
\hline Apartments (\%) & 49.5 & 63.4 & 4.3 \\
\hline Constructed before 1986 & 2,475 & 1,450 & $1,172,950$ \\
\hline Constructed after 1986 & 185 & 145 & 628,305 \\
\hline Average number of rooms & 5.5 & 5.2 & 6.3 \\
\hline Average household size & 2.4 & 2.5 & 2.8 \\
\hline Median monthly rents (\$) & 775 & 716 & 926 \\
\hline
\end{tabular}

Economically, family incomes (both personal and household) were below the Toronto average. Conversely, unemployment rates were above the Toronto average. A comparatively high share of the resident population had low incomes. Although the population of this area is often described as blue collar and working class, few residents still work in construction or manufacturing. In fact, business services are-as in Toronto as a whole- the most frequent occupation (Statistics Canada, Census, 2006). 
Income and Employment Characteristics, 2006

\begin{tabular}{|l|r|r|r|}
\hline & $\begin{array}{l}\text { Census } \\
\text { Tract 26 }\end{array}$ & $\begin{array}{l}\text { Census } \\
\text { Tract 74 }\end{array}$ & $\begin{array}{l}\text { Toronto } \\
(\text { CMA })\end{array}$ \\
\hline Median earnings, 15 + years (\$) & 29,704 & 26,862 & 30,350 \\
\hline Median household income (\$) & 46,490 & 48,189 & 64,128 \\
\hline Persons with low income before tax (\%) & 28.5 & 32.5 & 18.4 \\
\hline Persons with low income after tax (\%) & 23.5 & 26.5 & 14.4 \\
\hline Unemployment rate & 10.8 & 9.6 & 6.7 \\
\hline
\end{tabular}

Source: Statistics Canada, Census, 2006

Immigration and Visible Minority Population, 2006

\begin{tabular}{|c|c|c|c|}
\hline & \begin{tabular}{|l|} 
Census \\
Tract 26 \\
\end{tabular} & $\begin{array}{l}\text { Census } \\
\text { Tract } 74\end{array}$ & $\begin{array}{l}\text { Toronto } \\
\text { (CMA) }\end{array}$ \\
\hline \multicolumn{4}{|l|}{ Immigration } \\
\hline Immigrants & 2,355 & 1,635 & $2,320,165$ \\
\hline Before 1991 & 1,200 & 760 & $1,152,045$ \\
\hline 1991 to 2000 & 675 & 615 & 720,185 \\
\hline 2001 to 2006 & 480 & 260 & 447,925 \\
\hline Non-permanent residents & 110 & 105 & 76,320 \\
\hline \multicolumn{4}{|l|}{ Visible Minorities } \\
\hline Total visible minority population & 2,610 & 1,995 & $2,174,070$ \\
\hline Chinese & 1,145 & 975 & 486,330 \\
\hline South Asian & 630 & 480 & 684,070 \\
\hline Black & 320 & 200 & 352,220 \\
\hline Filipino & 150 & 55 & 171,980 \\
\hline Latin American & 35 & 10 & 99,295 \\
\hline Southeast Asian & 150 & 95 & 70,215 \\
\hline Arab & 10 & 15 & 53,430 \\
\hline West Asian & 25 & 0 & 75,475 \\
\hline Korean & 10 & 0 & 55,265 \\
\hline Japanese & 40 & 60 & 19,010 \\
\hline Visible minority; n.i.e. & 20 & 55 & 46,705 \\
\hline Multiple visible minority & 75 & 45 & 60,075 \\
\hline Not a visible minority & 3,880 & 2,015 & $2,898,005$ \\
\hline Aboriginal & 140 & 55 & 26,575 \\
\hline
\end{tabular}

Source: Statistics Canada, Census, 2006

Contrary to the ethnic identity of "Little India", fewer immigrants live in the area compared to the Toronto CMA as whole. In the census tracts north and south of Gerrard St. immigrants comprise 40.6 percent and 36.2 percent of all residents, respectively. While these percentages are lower than the Toronto average of 45.4 percent, they are higher than those of some areas further east. Furthermore, most residents do not belong to a so-called "visible minority" group. Moreover, Chinese, rather than South Asians, are the largest visible minority group. South 
Asians (a group that encompasses an enormous array of diverse ethnic, linguistic and religious affiliations) are the second largest group, followed by Blacks, South Asians and Filipinos. The Aboriginal population (not a "visible minority") is relatively small.

\section{Racism and Resistance}

Demographic changes (or the perception thereof) were associated with racial and ethnic tensions and anxieties about cultural transformation. A prominent manifestation of these tensions and anxieties was the establishment of a local chapter, with a Danforth mailing address, of the National Rights Party, a white supremacist political order based in Georgia, USA. The group distributed pamphlets and recruitment materials. In 1965, the post-master general banned the group from distributing hate-inciting paraphernalia. This distribution ban, however, did not settle the matter. The Ku-Klux Klan (KKK) opened an office at 1439 Dundas St. East and incited hatred against Jews, 'eastern' religions and 'blacks'. Furthermore, the KKK distributed recruitment material and white supremacist propaganda, including "KKK Canada White Youth Corp” literature, in Monarch Park Secondary School and other local institutions. James McQuirter, the Canadian spokesperson for the Klan, also lived in Riverdale. In response to these developments, a resistance group - the Riverdale Action Committee Against Racism (RACAR)—formed in Toronto. Eventually, the KKK office was forced to close (Greenwood Study Group, 1987; Robbins, 1981; Young, no date; Ward 8 News, 1980b).

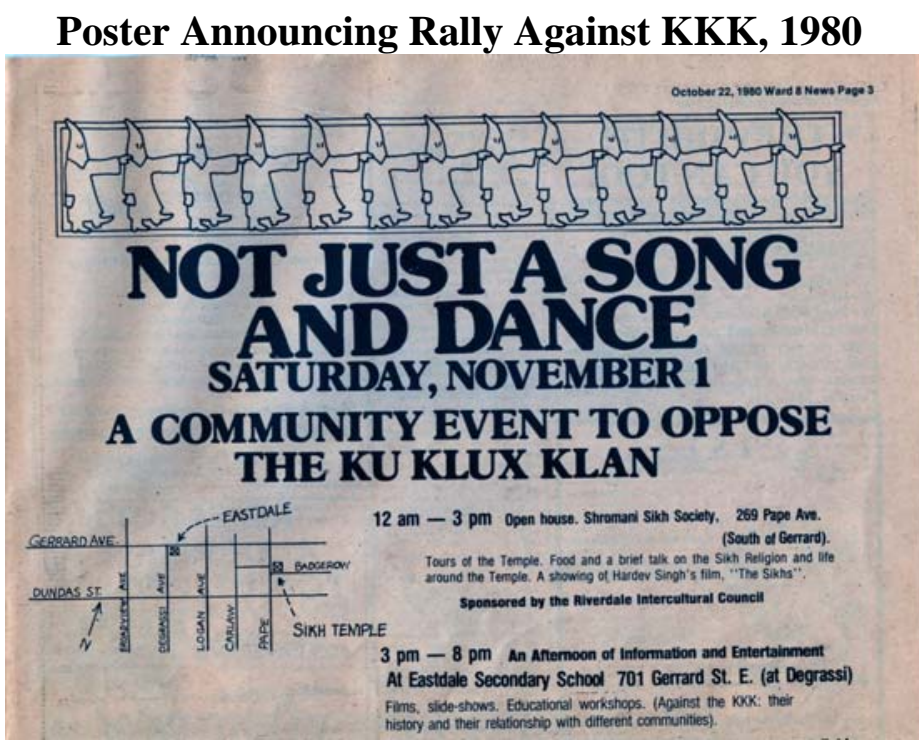

Source: Ward 8 News, 1980c.

In 1977, Don McCellan reported in the magazine Toronto Life that an East Indian anti-racist group in Toronto's east end created a 24-hour emergency hot line for those who encountered racist attacks. Although the group denied that it was motivated by vigilantism, it defended violence as a means to "support the struggle of poor whites, blacks, and Orientals". Apparently, sections of the South Asian population "felt compelled to arm themselves when police turned a blind eye” (Brouse, 2005). A few years later, the Toronto Star (1980b) reported about complaints from the local South Asian population about police prejudice and warned that the lack of protection would encourage the local immigrant population to "form strong-arm groups to protect their own people”. 
Racial tension also penetrated local everyday interactions between people. In the late 1970s, disputes about parking spaces emerged between South-Asian merchants and local residents. In light of these disputes a ‘South-Asian’ merchant sent a letter to the Ontario Human Rights Commission complaining about the verbal harassment of one of his co-ethnic patrons by a resident over a parking spot (Historical Collection, 1978). These tensions surfaced again later when someone posted signs on telephone poles, proclaiming "Gerrard Forever!" to resist the proposal to rename Gerrard St. East to Mahatma Gandhi Boulevard (Brouse, 2005).

The Greenwood Study Group (1987) reported about rising tensions between "East Indians” and Sikh populations [sic]. Media reports on ethnic conflict increased in the late 1990s, with an intensifying rivalry among “Tamil gangs”, such as VVT named after the town Valvettithurai in northern Sri Lanka, and AK Kanon named after the Russian-made assault rifle. Although these gangs were not confined to the local neighbourhood (Murray, 1998), the area became the centre of media attention in November, 1998, when a stabbing occurred in the core of Little India's commercial district that, according to police, may have involved "as many as 50 young people with knives, meat cleavers and homemade spears” (Globe and Mail, 1998).

\section{Business and Work}

\section{Early Industry and Commerce}

The working-class identity, which the area possessed throughout much of its history, was enforced by the types of local industries that prevailed. Early industries included many brickyards. Along Greenwood Ave, south of Grand Trunk Railway, were brickyards named John Price J. Morley, J. Ashbridge, Bell Brothers, Morley and Ashbridge, T. Sawden and David Wagstaff. One of the clay mines is now the site of Greenwood Park; another mine was located at Monarch Park (Beverly, no date).

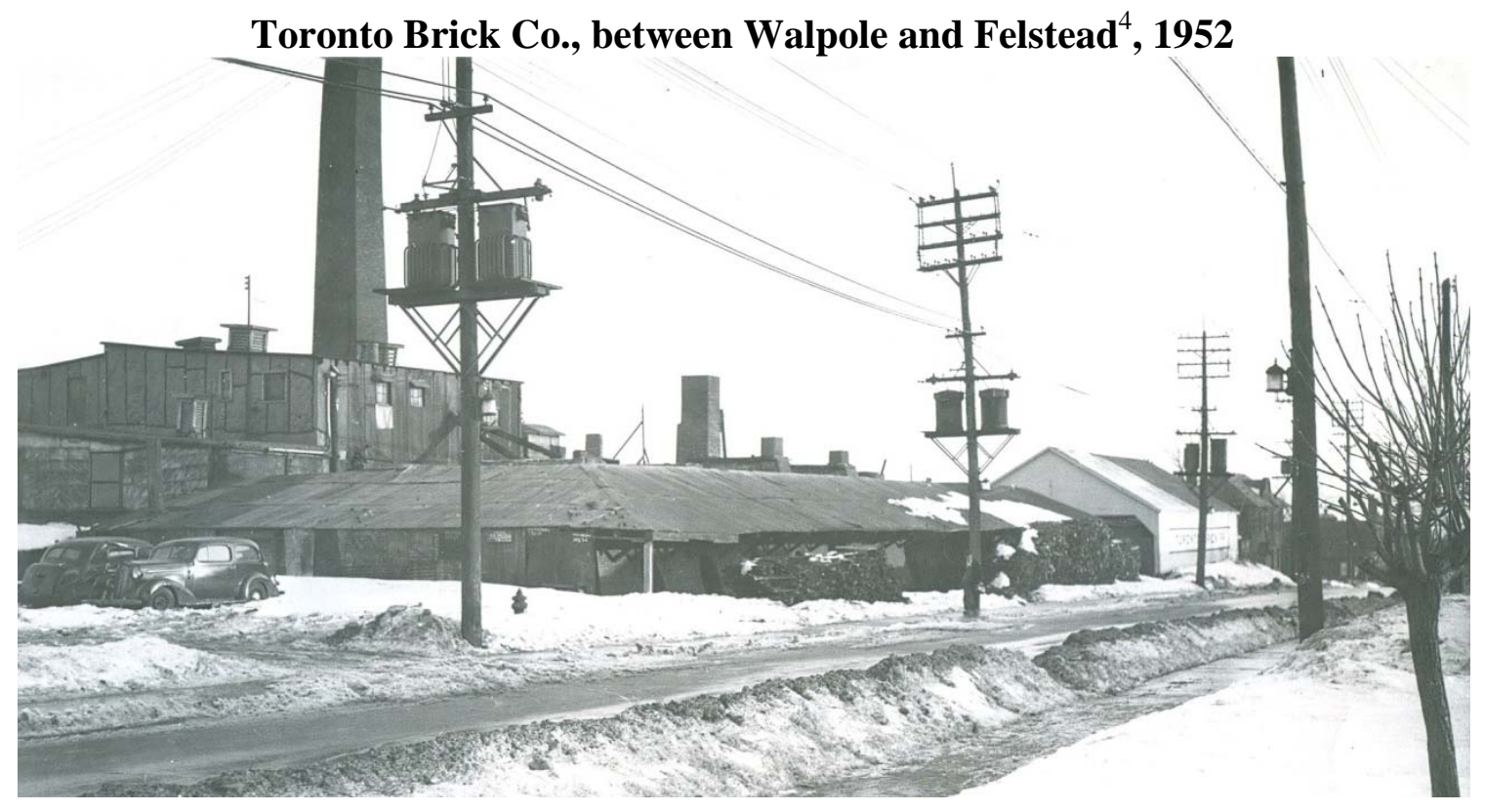

\footnotetext{
${ }^{4}$ The location was given in the photo's title as it was filed in the Toronto Public Library Archives
} 
In terms of commercial activity, a variety of stores and businesses were established in the 1870s and 1880s by English, Scottish, Irish and American immigrant entrepreneurs along Kingston Rd. Further north, commercial activities became established in the subsequent decades, with local residential development. Commercial activities along Gerrard St. East tended to service the needs of the local resident population. For example, in 1916, J.A. Dellow opened a store at 1340 Gerrard St. E. for the sale and repair of bicycles, sporting goods, tires, lawn mowers and other products. Stores were typically family-owned businesses and included appliance, jewelry, hardware and electronic stores, food markets and gas stations. There were several theatres located along Gerrard St. between Greenwood and Coxwell (Robinson, 1885; Commercial, industrial and progressive edition of east Toronto and the beaches, 1918).

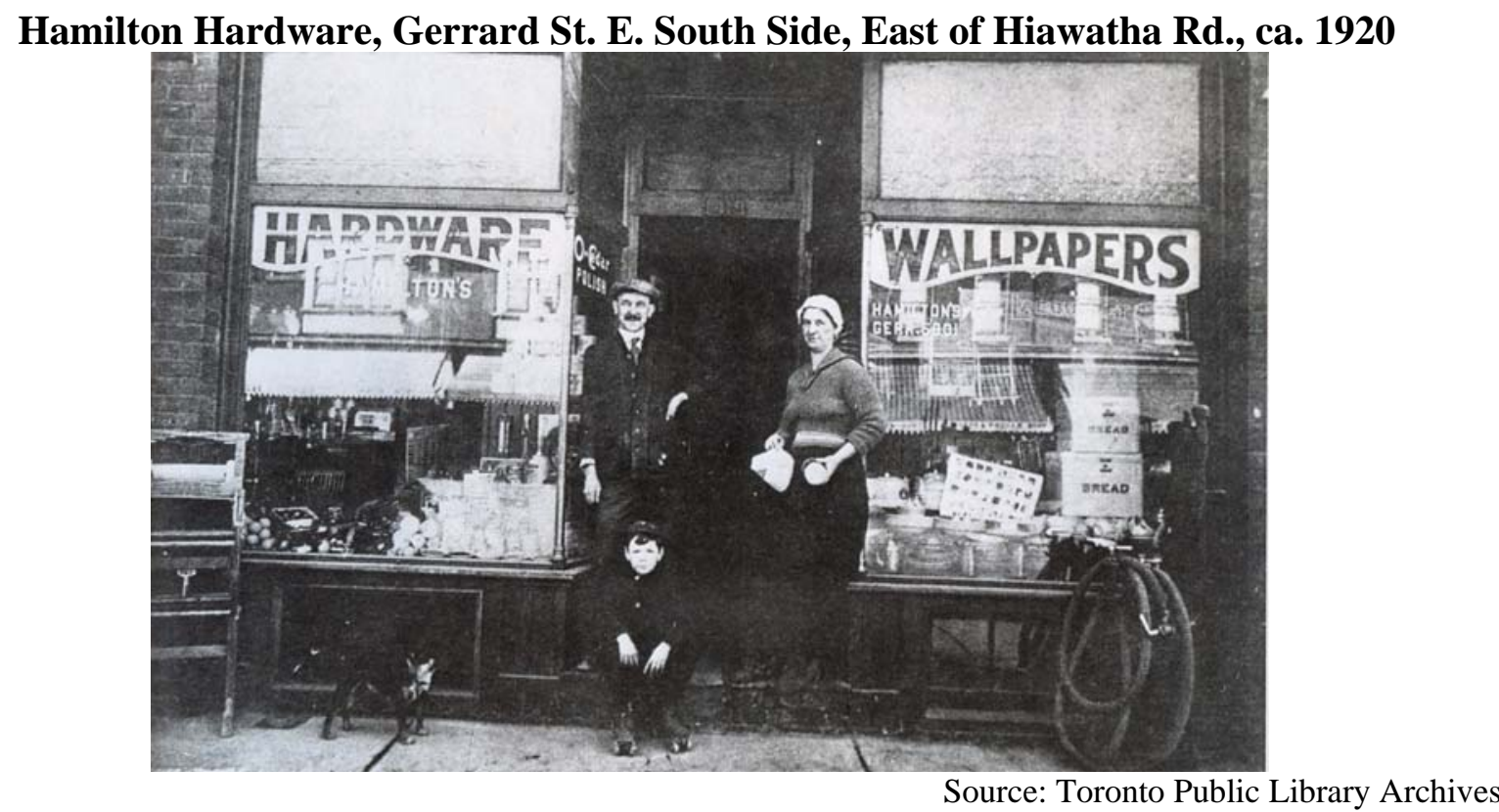

\section{The Emergence of Little India}

By the late 1960s, business and commercial enterprises along Gerrard St. were in decline. Wally Hamilton, the owner of Hamilton Hardware since 1917, commented in the Toronto Star in 1969 that there were five or six empty businesses in the immediate vicinity (Stein, 1984).

The commercial trajectory of the area changed dramatically in 1972, when Gian Naaz, an immigrant from India, rented the then-defunct Eastwood Theatre, which had a capacity to seat 750 viewers, and started showing $35 \mathrm{~mm}$ films in Hindi and other South-Asian dialects. Naaz had previously shown $16 \mathrm{~mm}$ films in rented school auditoriums and found financial supporters and partners, by going door to door, to establish the movie theatre and acquire the rights to show films. He reportedly said that he "wanted a place where Indians could meet socially and where women would have a reason to wear saris" at an establishment close to downtown. Due to the success of his enterprise, Naaz was able to buy the theatre in 1974 for $\$ 10,000$ and named it Naaz Theatres. The building also contained 8 commercial units (Bruzal, 1982; Oliveira, 2000; Paradkar, 2000). 


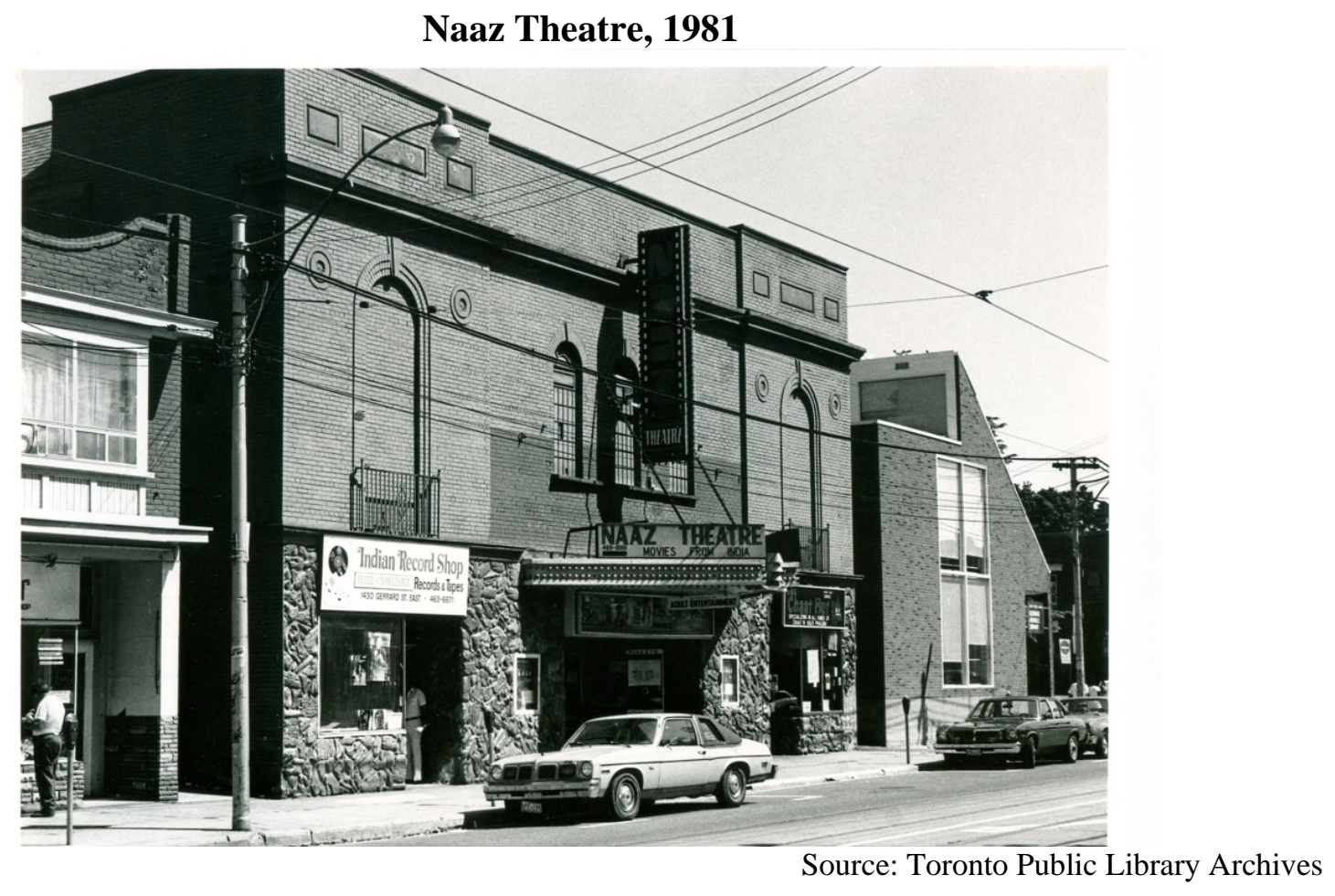

The Naaz Theatre stimulated commercial development along Gerrard St. East, between Woodfield and Coxwell, reversing the local economic decline of prior years. In particular, it attracted other Indian and Pakistani businesses and more recently Sri Lankan and Bangladeshi enterprises, which gave the area its distinct commercial identity (Bruzal, 1982; Stein, 1984; Oliveira, 2000).

The Indian restaurant Skylark (now Nitya Cuisines of India), across the street from the Naaz Theatre, reportedly opened in 1974. Among the early stores that were attracted by the Naaz Theatre was Milan's Department Store, which sold a variety of items including saris and paan. The conversion of a former I.P.A. store into Amitabh Shopping Mall, named after the famous movie actor Amitabh Bachan, received considerable local and media attention. The mall contained six take-out restaurants and numerous stores, rented mostly to tenants of East Indian origin. Although this particular mall did not survive, the general area continued to attract ethnic businesses (Toronto Star, 1980a, 2000; Ward 8 News, 1980a).

By the 1980s, “Little India” was firmly established. The area contained approximately 100 South Asian shops and restaurants and received an estimated 100,000 tourists in 1984, including visitors from as far as Detroit ${ }^{5}$. A proposal suggested to close Gerrard St. between Woodfield and Gerrard to automobile traffic during the summer months or on weekends. The South Asian business identity was further congealed when the City of Toronto approved the Gerrard India Bazaar Business Improvement Area (BIA) between Craven Rd. and Woodfield Rd. in July, 1982 (Gerrard Indian Bazaar News, 1982; Heighton, 1985; Leroy, 1978; Stein, 1984; Toronto Star, 1980a).

\footnotetext{
${ }^{5}$ One restaurant owner reported once selling $\$ 700$ worth of carry-out food to a Detroit family who took the food home for a wedding reception (Toronto Star, 1980a).
} 


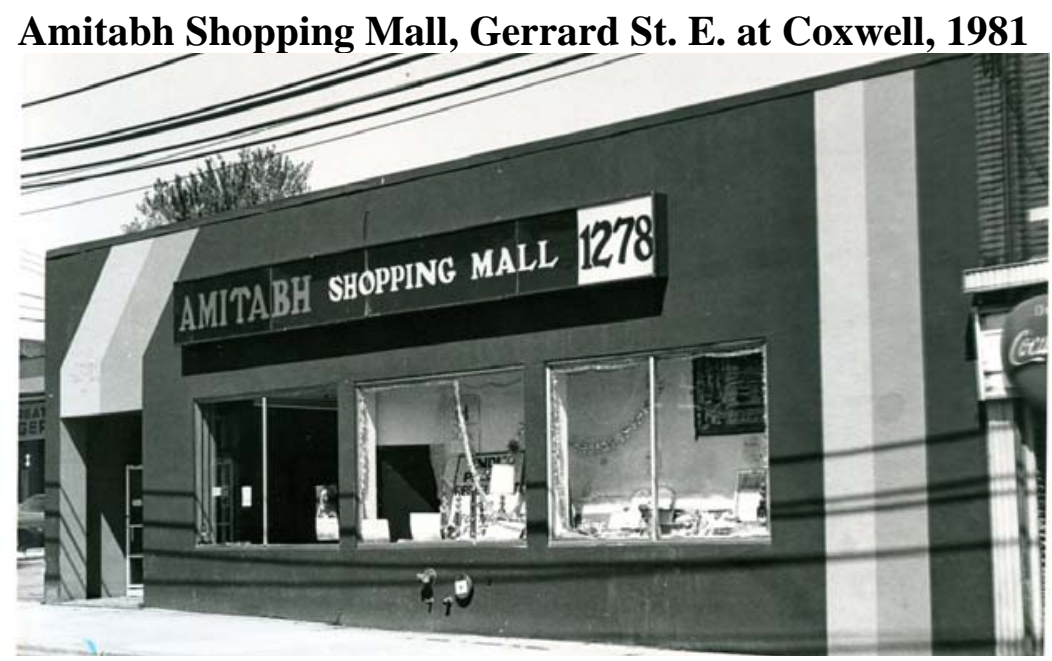

Source: photo by Peter Scott, Toronto Public Library Archives

In the early 1980s, concerns emerged about deteriorating buildings and storefront façades, cracked sidewalks, insufficiently lighting, litter and parking problems. One survey reported 500 cars passing through the area within a 30 min period on a Sunday afternoon. Furthermore, cars were parked on private lawns and driveways, resulting in tensions between local residents and businesses. In an effort to address these problems, the BIA announced new street lighting and the availability of Roden Public School for parking to shoppers (Gerrard Indian Bazaar News, 1982 (Heighton, 1985; Snider, 1984; Toronto Star, 1980a).

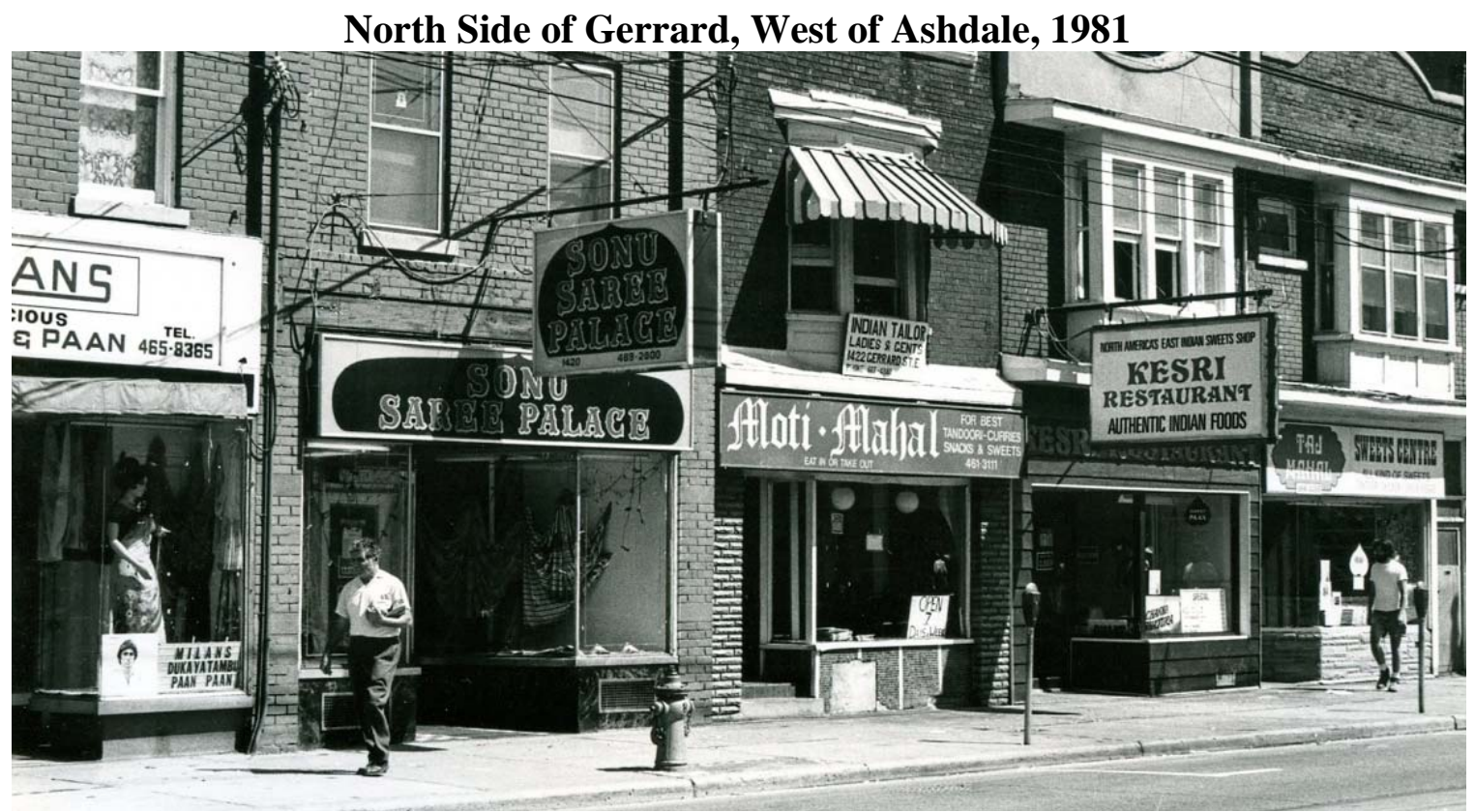

Source: photo by Peter Scott, Toronto Public Library Archives 


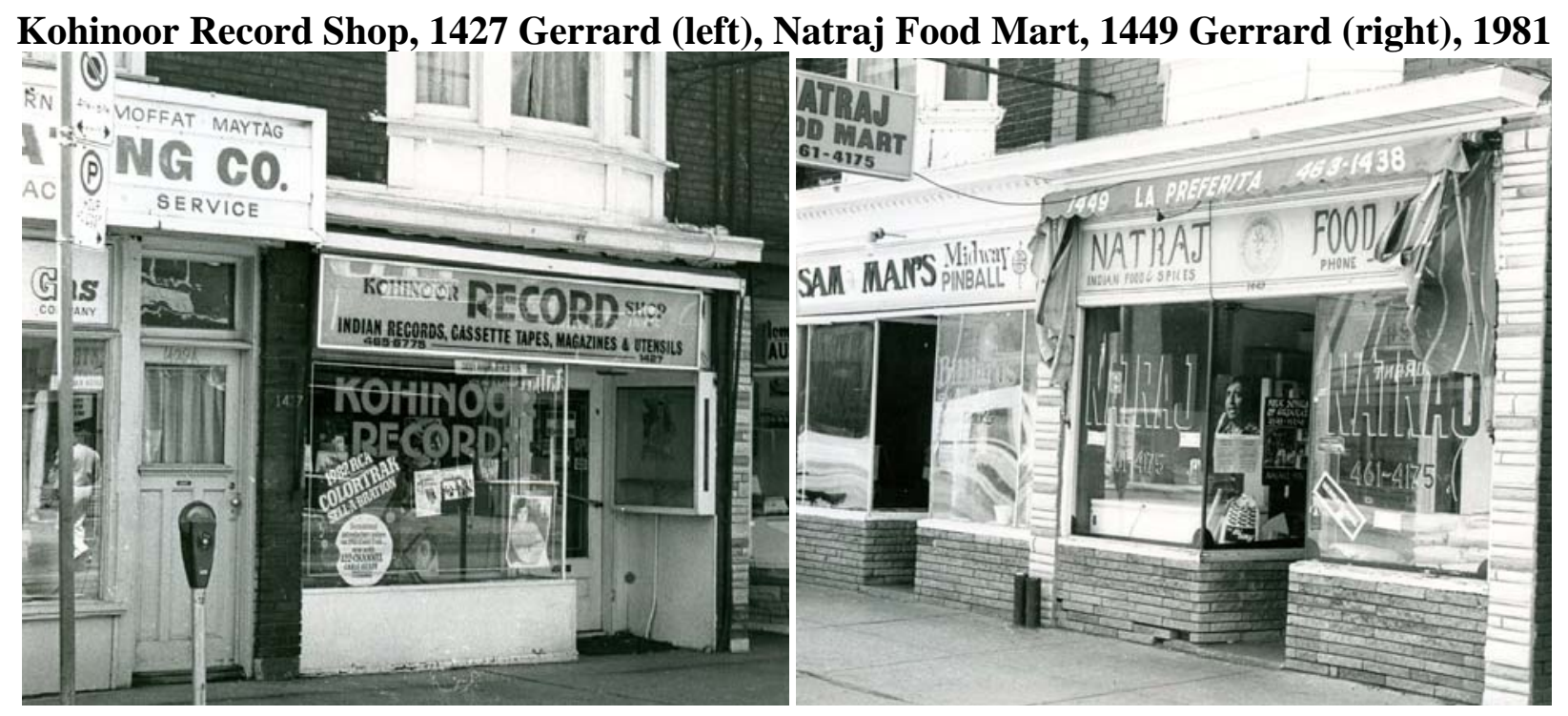

Source: photo by Peter Scott, Toronto Public Library Archives

The BIA played an important role in maintaining the viability of the commercial area. The area reinforced its status as a destination for tourists from other parts of Ontario and the United States. In the early 2000s, an estimated 40 percent of customers were from the United States, with some visitors coming from Buffalo for lunch (Fraser, 2003; Hutsul, 2004). Most business owners, however, reportedly live outside the geographical area, thus uncoupling the commercial and residential identities of the community.

In last two decades, the ethnic commercial area has experienced several challenges. In Toronto's suburbs, such as Brampton and Mississauga, where many immigrants have recently settled (Bauder and Sharpe, 2002), stores and malls are increasingly catering to this clientele, while suburban movie theatres have discovered Bollywood. These developments have drawn customers away from Gerrard St. In addition, technology and telecommunication advancements enable immigrant families to see movies and receive cultural programming at home. Affected by these developments, the Naaz Theatre closed in the late 1990s; only a small mall remained in the building. Furthermore, the SARS outbreak and the racial and religious profiling at the CanadaUS border that followed the attacks of September 11, 2001, caused a dramatic drop in the number of visitors from the USA (Brouse, 2005; Hutsul, 2004; Fraser, 2003).

Local ethnic businesses are increasingly seeking to attract a "mainstream" Canadian clientele and are exploring corresponding urban design strategies (Kumar and Martin, 2004). The bazaar celebrates Muslim Eid, Hindu Diwali, Sikh Vaisakhi, as well as Christian Christmas. This strategy also includes an annual street festival that attracts 50,000-100,000 visitors who spend more than estimated \$2 million. The BIA is further looking for solutions, including urban design strategies. 


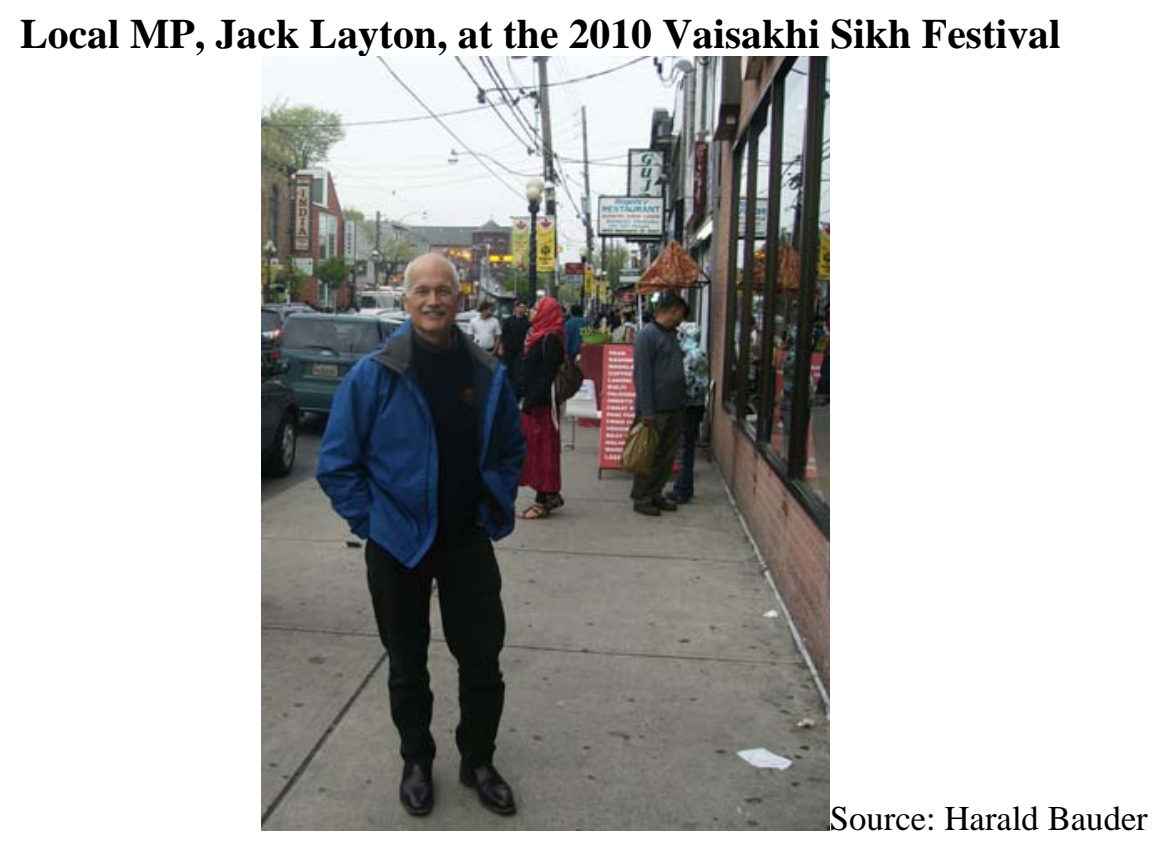

\section{Outlook}

The disconnection between local residential and commercial communities defines the area north and south of Gerrard St. East between Greenwood Ave. and Coxwell Ave. On the one hand, this disconnection reflects the unusual development of an ethnic business enclave without the prior presence of a corresponding ethnic residential community. On the other hand, the disconnection between residential and commercial communities is nothing unusual. Throughout North America, former immigrant reception centres, such as Little Italies and Greektowns, have gentrified, leading to the displacement of the original populations and the attraction of middleclass and non-immigrant populations who appreciate the image of the "ethnic" neighbourhood as an aesthetical expression of lifestyle (Ley, 1996, 2003; Smith, 1996).

Although Little India and its surrounding residential areas may not yet have gentrified to the same degree as other neighbourhoods in East Toronto, signs of gentrification are on the horizon. Elsewhere, gentrification has lead to rising real estate values and decreasing levels of social diversity and interaction, declining immigrant populations and the displacement of ethnic businesses (Hackworth \& Rekers, 2005; Lees, 2008; Walks \& August, 2008). As many employees of ethnic businesses, residents of local public housing, rooming houses, supportive housing and some families in co-op and private-market housing struggle with low incomes, more affluent residents are moving into the area. Socio-economic class may become an emerging source of division within the local community.

Residential gentrification, however, may not hurt ethnic businesses. The India Bazaar commercial area has never depended to the same degree on a neighourhood customer base as other ethnic enclave economies. Rather, ethnic businesses are depending on non-local circumstances and developments, including residential and commercial suburbanization. One possibility for economic renewal is to re-establish the area as a regional "destination" for ethnic consumption. An additional opportunity may rest with the changing residential community and 
its appreciation of the area's ethnic identity. The latter may help the local business community to maintain its viability while meeting the residential community's aesthetical and lifestyle preferences.

A new local initiative is the Riverdale HUB (www.riverdalehub.ca), aiming to find a model of co-existence where people of different classes, races, genders, sexualities, etc. can occupy common places and spaces. This initiative brings together artists, environmentalists and service groups ${ }^{6}$ in an effort to revitalize Little India while including-not displacing-existing residents and businesses. If successful, the HUB can serve as a model for an integrative communitydevelopment initiative.

\section{References}

Acarya, Madhavi, 1997. Smell of incense, rustle of silk, little India a feast for the senses. Toronto Star. July 21: L13.

Bauder, Harald and Bob Sharpe. 2002. Visible minorities in Canada's gateway cities. The Canadian Geographer 46(3): 204-222.

Beverly, Ted. No year. The Neighbourhood Around Gerrard/Ashdale: An Annotated Bibliography. Introduction by Ruth E. Wallace. Toronto: Toronto Public Library, Gerrard/Ashdale Branch.

Broadview Gospel Hall. 2001. 100 Years of Assembly Testimony. http://www.broadview.gospelhall.com/book_100yrs_with_cover.pdf

Brouse, Cynthia. 2005. Indian summer. Toronto Life. September: 29-38.

Bruzual, Ken. 1982. Caribbean foods at new East Indian mall. Contrast. September 24 .

Bungee, William. 1971. Fitzgerald: Geography of a Revolution. Cambridge, Mass.: Schenkman Publishers.

Canada Mortgage and Housing Corporation. 2010. Coxwell Stables - Toronto, Ontario. http://www.cmhc-schl.gc.ca/en/inpr/afhoce/tore/afhoid/rere/conorebu/conorebu_005.cfm

CFL (Canadian Football League). 2010. Timeline 1930s. http://www.cfl.ca/page/his_timeline_1930

Commercial, industrial and progressive edition of east Toronto and the beaches. 1918. Pamphlet.

Dodd, George. 1964. Norway and East Toronto at the Turn of the Century. Toronto: York Pioneer and Historical Society.

Fraser, John. 2003. Pakistan Celebrates I-Day. India Journal. 2003. August 22: 6-7.

Glen Rhodes United Church. 2010. The History of Glen Rhodes Church. http://www.glenrhodesunitedchurch.ca/Page.asp?PageID=122\&ContentID=442

Gerrard India Bazaar News. 1982. Vol 1. No 1. Toronto.

Globe and Mail. 1998. Rival Tamil gang scuffles end in one arrest. November 24.

Greenwood Study Group. 1987. The Greenwood Study: Race Relations. Toronto: 26-28

Guillet, Edwin. 1946. Pioneer Life in the County of York. Toronto: Hess-Trade.

Hackworth, Jason and Josephine Rekers. 2005. Ethnic packaging and gentrification: The case of four neighborhoods in Toronto. Urban Affairs Review 41(2): 211-236.

\footnotetext{
${ }^{6}$ Social enterprises include a fair trade cafe, Global Pantry, a catering enterprise and Copy/Chai, a desk top publishing copy centre for youth (being planned). A community kitchen in the basement is planned.
} 
Heighton, Nancy. 1985. Gerrard Indian Bazaar Meeting., July 11/12.

Hutsul, Chris. 2004. Sub continental drift. Toronto Star. Metropolis.. January 18: B1-B2

Kumar, Sandeep and George Martin. 2004. A case for culturally responsive urban design: Urban design meets Bollywood. The Ontario Planning Journal 19(5): 5-7

Lees, Loretta. 2008. Gentrification and social mixing: Towards an inclusive urban renaissance? Urban Studies 45(12): 2449-2470.

Leroy, Ian. 1978. Mall on Gerrard St. E may solve several problems. Ward 8 News. 20 July.

Ley, David. 1996. The New Middle Class and the Remaking of the Central City. Oxford: Oxford University Press.

Ley, David. 2003. Artists, aestheticisation and the field of gentrification, Urban Studies, 40(12): 2527-2544.

Murray, Maureen. 1998. Tamil gang truce comes undone. Toronto Star. December 3: B1 \& B9

Historical Collection. 1978. More schoolyard parking could ease racial tension, trustees told. vertical file. January 29.

McClellan, Don. 1977. Toronto Life. January.

Nasir, Muneeb. 2009. Planting the seeds - History of the Islamic Foundation of Toronto Part 2. Iqra, May 22. http://iqra.ca/?p=52

Oliveira, Lisa. 2000. Gerrard India Bazaar at the Crossroads. Undergraduate thesis. Toronto: University of Toronto, Department of Geography and Planning.

Robbins, Lynda. 1981. Klan update. Library Worker. Toronto.

Robinson, C. Blackett (publisher). 1885. History of Toronto and County of York. Vol.1, Part II. Toronto.

Smith, Neil. 1996. The New Urban Frontier: Gentrification and the Revanchist City. London: Routledge.

Snider, Bret. 1984. B.I.A. business community eligible for area improvement funds. The Advocate, July: 3.

Stein. David Lewis. 1984. Immigrants help revive Riverdale. Toronto Star. July 16.

Toronto Community Housing. 2010. Coxwell Stables. http://www.torontohousing.ca/market_rent_buildings/southeast_toronto/coxwell_stables

Toronto Star. 1980a. East Indian Mall Opens on Gerrard St. September 22.

Toronto Star. 1980b. Race relations, August 3.

Paradkar, Bagsheree. 2000. Gian Naaz brought India to Toronto. Toronto Star. January 18: B5

Statistics Canada, Census. 2006. http://www12.statcan.gc.ca/census-recensement/index-eng.cfm

Toronto Star. 2009. Neighbourhood map. March 22. (for updated version: thestar.com/maps)

TTC (Toronto Transit Commission). 1953. Wheels of Progress (Pamphlet): A Story of the Development of Toronto and its Public transportation Services, $5^{\text {th }}$ ed. Toronto: $94-122$.

Walks, Alan and Martine August. 2008. The factors inhibiting gentrification in areas with little non-market housing: Policy lessons from the Toronto experience. Urban Studies 45(12): 2594-2625.

Ward 8 News. 1980a. Bazaar features six restaurants. Vol 3. October 22-Nov. 14.

Ward 8 News. 1980a. Klan shows hand, prosecution planned. October 22: 1, 9

Ward 8 News. 1980c. RallyaAgainst KKK. October, Toronto: 3.

Young, Neil. No date. Condemnation for Klan-like groups. Ward 9 News. Toronto. 